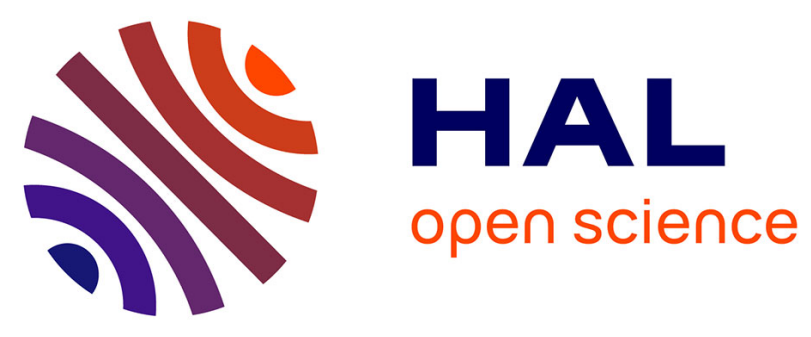

\title{
Insights into nitromethane combustion from detailed kinetic modeling - Pyrolysis experiments in jet-stirred and flow reactors
}

Krishna Prasad Shrestha, Nicolas Vin, Olivier Herbinet, Lars Seidel, Frédérique Battin-Leclerc, Thomas Zeuch, Fabian Mauss

\section{To cite this version:}

Krishna Prasad Shrestha, Nicolas Vin, Olivier Herbinet, Lars Seidel, Frédérique Battin-Leclerc, et al.. Insights into nitromethane combustion from detailed kinetic modeling - Pyrolysis experiments in jet-stirred and flow reactors. Fuel, 2020, 261, pp.116349. 10.1016/j.fuel.2019.116349 . hal-02320515

\section{HAL Id: hal-02320515 \\ https://hal.science/hal-02320515}

Submitted on 18 Oct 2019

HAL is a multi-disciplinary open access archive for the deposit and dissemination of scientific research documents, whether they are published or not. The documents may come from teaching and research institutions in France or abroad, or from public or private research centers.
L'archive ouverte pluridisciplinaire HAL, est destinée au dépôt et à la diffusion de documents scientifiques de niveau recherche, publiés ou non, émanant des établissements d'enseignement et de recherche français ou étrangers, des laboratoires publics ou privés. 


\title{
Insights into nitromethane combustion from detailed kinetic modeling - Pyrolysis experiments in jet-stirred and flow reactors
}

\author{
Prasad Shresthaa, Nicolas Vin' , Olivier Herbinet ${ }^{b}$, Lars Seidelc, ${ }^{*}$, \\ Frédérique Battin-Leclerc ${ }^{b}$, Thomas Zeuchd, Fabian Mauss ${ }^{a}$
}

a Thermodynamics and Thermal Process Engineering, Brandenburg University of Technology, Siemens-Halske-Ring 8, 03046 Cottbus, Germany

${ }^{b}$ Laboratoire Réactions et Génie des Procédés, CNRS, Université de Lorraine, BP 20451, 1 rue Grandville, 54000 Nancy, France

${ }^{c}$ LOGE Deutschland GmbH, Burger Chaussee 25, 03044 Cottbus, Germany

d Institut für Physikalische Chemie, Georg-August-Universität Göttingen, Tammannstraße 6, 37077 Göttingen, Germany

Published in Fuel (2020), 261, 116349

\section{Highlights}

- New Pyrolysis experiments of nitromethane in jet-stirred and flow reactors.

- A detailed mechanism for the pyrolysis and oxidation of nitromethane is developed.

- $\mathrm{CH}_{3}+\mathrm{NO}_{2} \leftrightharpoons \mathrm{CH}_{3} \mathrm{O}+\mathrm{NO}$ is found to be the most important reaction.

- $\mathrm{CH}_{3} \mathrm{NO}_{2}(+\mathrm{M}) \leftrightharpoons \mathrm{CH}_{3}+\mathrm{NO}_{2}(+\mathrm{M})$ is the main reaction for nitromethane decomposition.

\section{Abstract}

The pyrolysis of nitromethane highly diluted in helium was studied in a plug flow reactor and in a jet-stirred reactor at 1.07 bar and over the temperature range from 500 to $1100 \mathrm{~K}$. Mole fraction profiles of major products and of intermediates were identified with gas chromatography and Fourier transform infrared spectroscopy. Using these experimental data, as well as published ones, we have developed a newly compiled model for the prediction of the pyrolysis and of the

\footnotetext{
* Corresponding author: Lars.Seidel@logesoft.com
} 
oxidation of nitromethane in jet-stirred and flow reactors, freely propagating, and burnerstabilized premixed flames, as well as in shock-tubes. The experimental results from the present work and from the literature are interpreted with the help of the kinetic model derived here. This study mainly focuses on the analysis of speciation in different reactors. Among the nitrogenous species, NO is found to be a major product for pyrolysis and oxidation. The model suggests that for nitromethane pyrolysis and oxidation the thermal dissociation channel to $\mathrm{CH}_{3}$ and $\mathrm{NO}_{2}$ is the main reaction path for the nitromethane degradation followed by the $\mathrm{H}$-atom abstraction channel. The most sensitive reactions for nitromethane pyrolysis in a flow reactor and during pyrolysis and oxidation in a jet-stirred reactor are found to be $\mathrm{CH}_{3} \mathrm{NO}_{2}(+\mathrm{M}) \leftrightharpoons \mathrm{CH}_{3}+\mathrm{NO}_{2}(+\mathrm{M})$ and $\mathrm{CH}_{3}+\mathrm{NO}_{2} \leftrightharpoons \mathrm{CH}_{3} \mathrm{O}+\mathrm{NO}$. The reaction $\mathrm{CH}_{3}+\mathrm{NO}_{2} \leftrightharpoons \mathrm{CH}_{3} \mathrm{O}+\mathrm{NO}$ is found to be the most important reaction for all conditions studied. In a burner-stabilized premixed flame, as the mixture gets richer, the thermal dissociation channel $\mathrm{CH}_{3} \mathrm{NO}_{2}(+\mathrm{M}) \leftrightharpoons \mathrm{CH}_{3}+\mathrm{NO}_{2}(+\mathrm{M})$ becomes more important as the contribution of the $\mathrm{H}$-atom abstraction channel is decreased. Furthermore, in the burnerstabilized premixed flames, it was found that $\mathrm{NO}$ is mainly formed via $\mathrm{NO}_{2}: \mathrm{NO}_{2}+\mathrm{H} \leftrightharpoons \mathrm{NO}+\mathrm{OH}$, $\mathrm{NO}_{2}+\mathrm{CH}_{3} \leftrightharpoons \mathrm{CH}_{3} \mathrm{O}+\mathrm{NO}$. The model provided an overall reasonable agreement with the experimental data. However, for pyrolysis conditions, future work is desirable to improve predictions of intermediate species. This work extends the kinetic database and helps to improve the understanding of nitromethane chemistry. The kinetic model presented in this work can serve as a base model for hydrocarbons and oxygenated fuels higher than $\mathrm{C}_{2}$ and nitrogen-containing compounds higher than $\mathrm{C}_{1}$ as well as for pure nitrogen compounds.

Keywords: Nitromethane, Pyrolysis, Oxidation, Jet-stirred reactor, Flow reactor, Kinetic modeling,

\section{Introduction}

The diminishing availability of conventional fuels and stricter regulations on pollution control and $\mathrm{CO}_{2}$ emission targets have led scientists and engineers to look for alternative fuels. Recently nitromethane has slowly gained interest as an alternative fuel or as a blend for internal combustion (IC) engines. Historically, a few detailed experimental studies have been conducted to determine the effect of engine and fuel operating parameters on the power output of an internal combustion engine using nitroparaffins as fuel. Nitromethane is one of the simplest nitroparaffins. In the past, it was mostly used as rocket propellant or as explosive and has been used as a reference fuel to understand the combustion mechanism of monopropellants [1-3]. Nitromethane is an energetic compound with a wide variety of applications, including its use as a monopropellant, a liquid explosive, a solvent for chemical processing and analysis, and a highperformance fuel additive for internal combustion engines and pulsed detonation engines $[4,5]$. The chemical formula of nitromethane is $\mathrm{CH}_{3} \mathrm{NO}_{2}$, it is liquid at room temperature (melting point $-29^{\circ} \mathrm{C}$ ) with a density of $1.138 \mathrm{~g} / \mathrm{cm} 3$ at $20^{\circ} \mathrm{C}$ and has a boiling point of $101.2^{\circ} \mathrm{C}$ [6]. In essence, it is the simplest of possible energetic $\mathrm{C}-\mathrm{H}-\mathrm{O}-\mathrm{N}$ molecules that contain a nitro group, which is why it is often used in reaction studies as a prototype for more complex energetic materials. It is partly soluble in aliphatic hydrocarbons, mostly soluble in aromatics, and highly soluble in lighter (e.g methanol) alcohols. If subjected to shock, it has a tendency to decompose with considerable 
violence and to explode in the manner of certain other organic nitrogen compounds [4]. Internal combustion engines are the commonly used propulsion system in passenger cars and racing cars. Glow plug two-stroke engines are often used to propel small-unmanned aerial vehicles and use a fuel mixture composed of methanol and a small quantity (5-20\%) of nitromethane [7]. The effect of nitromethane blends on the engine performance was studied by Starkman [4] and an increase in engine power was reported with nitromethane addition. The above finding was supported with other studies as well $[7,8]$. In drag racing, nitromethane is blended with gasoline to enhance the engine power output [9]. The lower heating value of nitromethane is $11.3 \mathrm{MJ} / \mathrm{kg}$ while for gasoline it is $42-44 \mathrm{MJ} / \mathrm{kg}$. The amount of air required to burn $1 \mathrm{~kg}$ of gasoline is approximately $14.7 \mathrm{~kg}$ while $1 \mathrm{~kg}$ of nitromethane only requires $1.7 \mathrm{~kg}$ of air. For a given engine cylinder volume 8.6 times more nitromethane can be burned than gasoline in one stroke. Hence, 2.3 times more power is generated compared to gasoline when combined with a given amount of oxygen [8]. The group of Yokoo et al. [10] investigated the effect of various fuel blends on the thermal efficiency of a sparkignited engine. They stated that the addition of $5 \%$ of nitromethane extended the lean limit operation and improved the thermal efficiency by 1-2\%. On the other hand, the research octane number (RON) is reduced by up to 5 points and the knock probability is increased. Similar characteristics are also reported by the group of Cracknell et al. [11] who studied the effect of 5\% addition of nitromethane to gasoline in a homogeneously charged compression ignition engine. However, detailed combustion aspects of nitromethane are not addressed in these works. As a pollutant from the automotive exhaust, nitromethane is also observed both experimentally in the laboratory and on-site from automobiles [12-14]. To investigate nitromethane combustion characteristics in engines through modeling as a pure fuel or as a blend, a reliable and comprehensive kinetic mechanism is needed.

Additionally, several explosives such as Trinitrotoluene or High Melting Explosive (also known as octogen) are major environmental contaminants as a result of their manufacture and deployment in both industrial and military applications, beside from the obvious physical hazards associated with explosives $[15,16]$. While incineration is the most common technique to treat soils contaminated by explosives [17], it can be a source of dioxins or other harmful compounds which then require additional disposal or further treatments [18]. Consequently, it is of interest to study an alternative process such as thermal decomposition. That is why it is of interest to study the thermal decomposition of nitromethane as a surrogate of octogen and also to better understand the chemistry of nitro compounds.

Though studies on nitromethane are not new, there are a number of studies on nitromethane detonation [19-21] and nitromethane decomposition [22-25]. None of these studies took into account the detailed kinetic study of $\mathrm{CH}_{3} \mathrm{NO}_{2}$ combustion. Glarborg et al. [26] calculated the reaction rate for the thermal dissociation of $\mathrm{CH}_{3} \mathrm{NO}_{2}\left(\mathrm{CH}_{3} \mathrm{NO}_{2}(+\mathrm{M}) \leftrightharpoons \mathrm{CH}_{3}+\mathrm{NO}_{2}(+\mathrm{M})\right)$ based on literature data and proposed a nitromethane mechanism validated only against the shock tube speciation from literature. Boyer and Kuo [2] proposed a detailed mechanism for nitromethane with 47 species and 250 reactions. However, their mechanism was dedicated to flame structure and burning rate only. When the work of Glarborg et al. [26] and Boyer and Kuo [2] was published, experimental data on the basic combustion features (ignition delay time, laminar flame speed) 
were not available in literature. Nauclér et al. [27] performed ignition delay time experiments of $\mathrm{CH}_{3} \mathrm{NO}_{2} / \mathrm{O}_{2} / \mathrm{N}_{2}$ in a shock tube and used two mechanisms from literature [28,29] to compare against their experimental data and mechanism predictions. Similarly, Brackmann et al. [30] measured the burning velocity of $\mathrm{CH}_{3} \mathrm{NO}_{2} / \mathrm{O}_{2}$ diluted with $\mathrm{CO}_{2}$ and the concentrations of $\mathrm{NO}, \mathrm{CO}$ and $\mathrm{CH}_{2} \mathrm{O}$ in two $\mathrm{CH}_{3} \mathrm{NO}_{2}$ flames (experimental condition shown in Table 1). They used the same two mechanisms $[28,29]$ as Nauclér et al. and compared model predictions and measurements. It was concluded in both studies that none of the mechanisms is able to accurately predict the experimental data $[27,30]$. They reached the similar conclusion that the nitromethane combustion chemistry is not fully understood, and further work is required to enable the construction of a kinetic mechanism with predictive capacity over a wide range of conditions.

Table 1: Experimental studies from literature and this work. py-: pyrolysis, ox-: oxidation Note: Temperature in burners are given for mixture inlet.

\begin{tabular}{|c|c|c|c|}
\hline Experimental devices & $\begin{array}{l}\text { Measured } \\
\text { properties }\end{array}$ & Experimental conditions & References \\
\hline Shock tube & $\begin{array}{l}\text { Ignition delay } \\
\text { times }\end{array}$ & $\begin{array}{l}2.0-30.0 \text { atm, } 875-1595 \mathrm{~K}, \phi= \\
0.5-2.0 \text { for } \mathrm{CH}_{3} \mathrm{NO}_{2} / \mathrm{O}_{2} / \mathrm{Ar}\end{array}$ & Mathieu et al. [29] \\
\hline Shock tube & $\begin{array}{l}\text { Ignition delay } \\
\text { times }\end{array}$ & $\begin{array}{l}8.0-32.0 \text { atm, } 947-1333 \mathrm{~K}, \phi= \\
0.5-2.0 \text { for } \mathrm{CH}_{3} \mathrm{NO}_{2} / \mathrm{O}_{2} / \mathrm{N}_{2}\end{array}$ & Nauclér et al. [27] \\
\hline Shock tube & $\begin{array}{l}\text { Ignition delay } \\
\text { times }\end{array}$ & $\begin{array}{l}2.0-10.0 \mathrm{~atm}, 1200-2000 \mathrm{~K}, \phi \\
=0.5-2.0 \text { for } \mathrm{CH}_{3} \mathrm{NO}_{2} / \mathrm{O}_{2} / \mathrm{Ar}\end{array}$ & Gao et al. [34] \\
\hline Flow reactor (py-) & Speciation & $\begin{array}{l}30,150 \text { and } 760 \text { Torr, } 750- \\
1400 \mathrm{~K} \text {, for } 5 \mathrm{~mol} \% \mathrm{CH}_{3} \mathrm{NO}_{2} / 95 \\
\mathrm{~mol} \% \mathrm{Ar}\end{array}$ & Jia et al. [35] \\
\hline Flow reactor (py-) & Speciation & $\begin{array}{l}5 \text { Torr, } 735-1476 \mathrm{~K} \text {, for } 5 \\
\text { mol\% } \mathrm{CH}_{3} \mathrm{NO}_{2} / 95 \mathrm{~mol} \% \mathrm{Ar}\end{array}$ & Weng et al. [36] \\
\hline Flow reactor (py-) & Speciation & $\begin{array}{l}1.07 \mathrm{bar}, 500-1100 \mathrm{~K} \text {, for } 1 \\
\mathrm{~mol} \% \mathrm{CH}_{3} \mathrm{NO}_{2} / 99 \mathrm{~mol} \% \mathrm{He}\end{array}$ & This work \\
\hline Jet stirred reactor (ox-) & Speciation & $\begin{array}{l}1 \text { atm, } 600-875 \mathrm{~K}, \phi=0.4 \text { and } \\
2.0 \text { for } \mathrm{CH}_{3} \mathrm{NO}_{2} / \mathrm{O}_{2} / \mathrm{Ar}\end{array}$ & Weng et al. [36] \\
\hline Jet stirred reactor (py-) & Speciation & $\begin{array}{l}1.07 \text { bar, } 500-1100 \mathrm{~K} \text {, for } 1 \\
\mathrm{~mol}_{0} \mathrm{CH}_{3} \mathrm{NO}_{2} / 99 \mathrm{~mol} \% \mathrm{He}\end{array}$ & This Work \\
\hline $\begin{array}{l}\text { Spherical combustion } \\
\text { chamber }\end{array}$ & $\begin{array}{l}\text { Laminar flame } \\
\text { speed }\end{array}$ & $\begin{array}{l}0.5-3.0 \text { bar, } 423 \mathrm{~K}, \phi=0.5- \\
1.3 \text { for } \mathrm{CH}_{3} \mathrm{NO}_{2} / \text { air }\end{array}$ & Brequigny et al. [28] \\
\hline Heat flux burner & $\begin{array}{l}\text { Laminar flame } \\
\text { speed }\end{array}$ & $\begin{array}{l}1 \text { atm, } 338-358 \mathrm{~K}, \phi=0.8-1.6 \\
\text { for } \mathrm{CH}_{3} \mathrm{NO}_{2} / \text { air }\end{array}$ & Nauclér et al. [37] \\
\hline Heat Flux burner & $\begin{array}{l}\text { Laminar flame } \\
\text { speed }\end{array}$ & $\begin{array}{l}1 \mathrm{~atm}, 348 \text { and } 358 \mathrm{~K}, \phi=0.8- \\
1.6 \text { for } \mathrm{CH}_{3} \mathrm{NO}_{2} / \mathrm{O}_{2} / \mathrm{CO}_{2}\end{array}$ & Brackmann et al. [30] \\
\hline McKenna Burner & Speciation & $\begin{array}{l}4.67 \mathrm{kPa}, 273 \mathrm{~K}, \phi=1.39 \text { for } \\
\mathrm{CH}_{3} \mathrm{NO}_{2} / \mathrm{O}_{2} / \mathrm{Ar}\end{array}$ & Tian et al. [38] \\
\hline McKenna Burner & Speciation & $\begin{array}{l}4.655 \mathrm{kPa}, 298 \mathrm{~K}, \phi=1.0-2.0 \\
\text { for } \mathrm{CH}_{3} \mathrm{NO}_{2} / \mathrm{O}_{2} / \mathrm{Ar}\end{array}$ & Zhang et al. [39] \\
\hline Heat Flux burner & Speciation & $\begin{array}{l}1 \mathrm{~atm}, 363 \mathrm{~K}, \phi=0.8 \text { and } 1.2 \text { for } \\
\mathrm{CH}_{3} \mathrm{NO}_{2} / \text { air } / \mathrm{N}_{2}\end{array}$ & Brackmann et al. [30] \\
\hline
\end{tabular}

Historically, there are only experimental studies or combined (numerical and experimental) studies, often dedicated to a single reactor at specific conditions or experimental setups. Recently, there have been various experimental studies on $\mathrm{CH}_{3} \mathrm{NO}_{2}$ due to which the development and validation of $\mathrm{CH}_{3} \mathrm{NO}_{2}$ models can be improved. They are summarized in Table 1 . However, to our best knowledge, there is no generally applicable kinetic model for $\mathrm{CH}_{3} \mathrm{NO}_{2}$ combustion covering 
also the $\mathrm{NO}_{\mathrm{x}}$ chemistry over a wide range of experimental conditions. This situation calls for an in-depth analysis of nitromethane $-\mathrm{NO}_{\mathrm{x}}$ chemistry interactions.

The aim of the present work is twofold:

1) to perform an experimental study of nitromethane pyrolysis in a tubular flow reactor and in a jet-stirred reactor, which will serve to extend the existing database and can be used for nitromethane model development.

2) to extend our recently published mechanism [31], which describes the oxidation of $\mathrm{CH}_{3} \mathrm{OH}$ and $\mathrm{C}_{2} \mathrm{H}_{5} \mathrm{OH}$ and its interaction with $\mathrm{NO}_{\mathrm{x}}$ (including $\mathrm{CH}_{3} \mathrm{NO}_{2}$ as a fuel), to subsequently study their interaction with hydrocarbon and nitrogen chemistry by considering the available experiments in the validation process.

To our best knowledge, no experimental pyrolysis study of nitromethane in a jet-stirred reactor has been published before and this work is the first to report such data. This work is an ongoing effort to develop a reliable and comprehensive mechanism for fuel/ $\mathrm{NO}_{\mathrm{x}}$ interaction taking into account detailed nitrogen chemistry. In addition, the model derived in this work is critically tested for laminar flame speeds (LFS), for ignition delay times (IDT), for speciation in jet-stirred reactors (JSR), in plug flow reactors (PFR), and burner stabilized flames (BSF). The development and compilation strategy for our baseline mechanism is described in our previous work [31,32] (which focused on $\mathrm{NH}_{3} / \mathrm{H}_{2} / \mathrm{CO} / \mathrm{CH}_{4}$ oxidation and $\mathrm{NO}_{\mathrm{x}}$ chemistry interaction). The present study is conducted in a similar manner. This makes the kinetic model more robust and reliable for combustion modeling under engine conditions (see section on $n$-heptane spray ignition in [33]).

\section{Experimental}

Experiments were carried out in two continuous flow reactors: a jet-stirred reactor (JSR) and a tubular reactor (TR) at a constant pressure of $1.07 \mathrm{bar}$, an inlet nitromethane mole fraction of 0.01 (high dilution in helium) and a residence time at the set-point temperature of $2.0 \mathrm{~s}$. The experimental setup used in this study is shown in Figure 1. In both reactors, species were sampled at the outlet and analyzed using gas chromatography and Fourier-Transform Infrared (FTIR) spectroscopy. The features of the two reactors and analytical procedure are described in the following paragraphs.

Helium was provided by Messer (purity of $99.999 \%$ ) and nitromethane was purchased from Sigma-Aldrich (purity of 98.5\%). Gas flow rates were controlled by mass flow controllers and the liquid flow rate by a Coriolis flow controller. The uncertainty in the flow measurements was around $0.5 \%$ for each controller, so about $1 \%$ on the residence time.

\subsection{Tubular reactor}

The tubular reactor set-up was developed recently in LRGP for kinetic studies at elevated temperatures [40] (up to $1300 \mathrm{~K}$ ) because this type of reactor is often used in industry for a variety of purposes. It consisted of an alumina tube (recrystallized alumina, volume of $294 \mathrm{~cm}^{3}$ ) 
with an inner diameter of $20 \mathrm{~mm}$ and an outer diameter of $25 \mathrm{~mm}$. The tubular reactor was heated by an electrical furnace from Vecstar. Temperature gradients along the tube were measured using a S-type thermocouple and are shown in Figure 2.

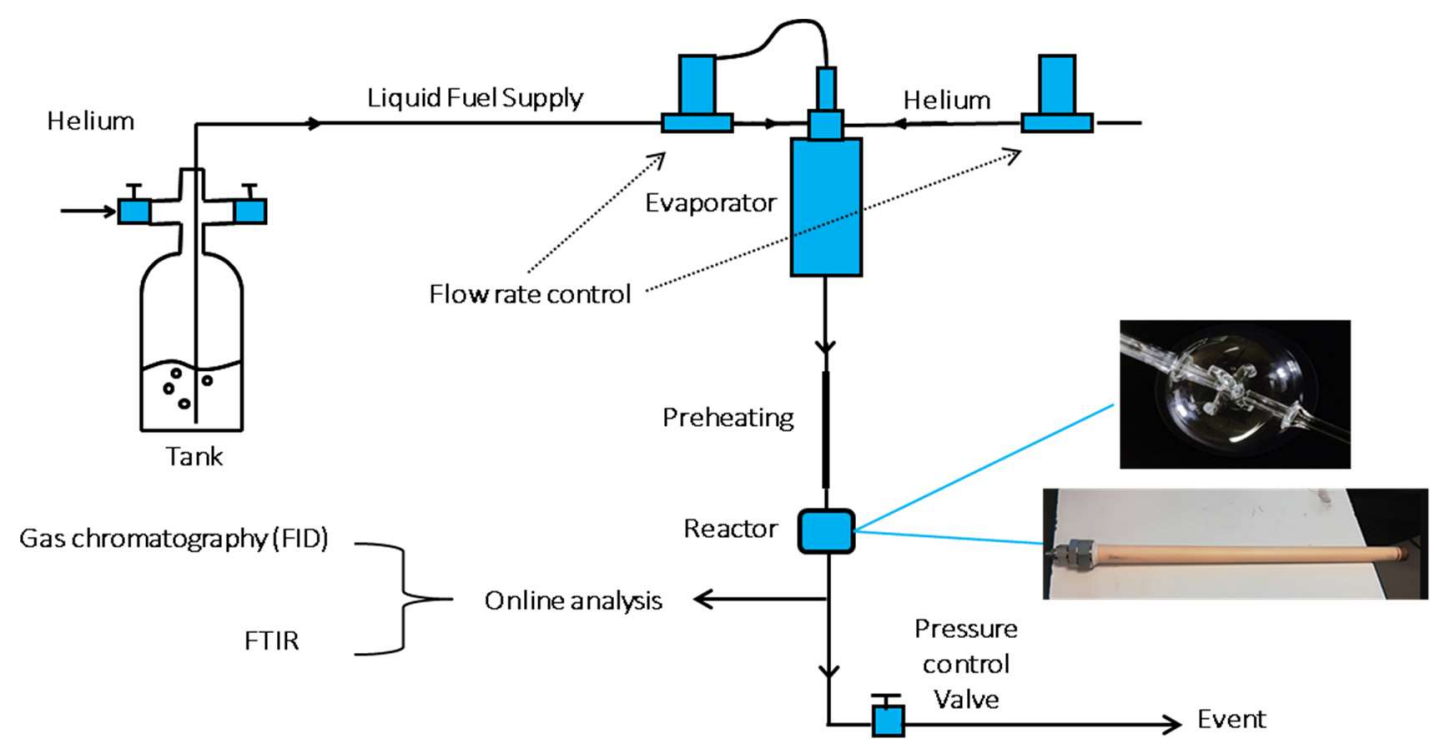

Figure 1: Experimental setup.

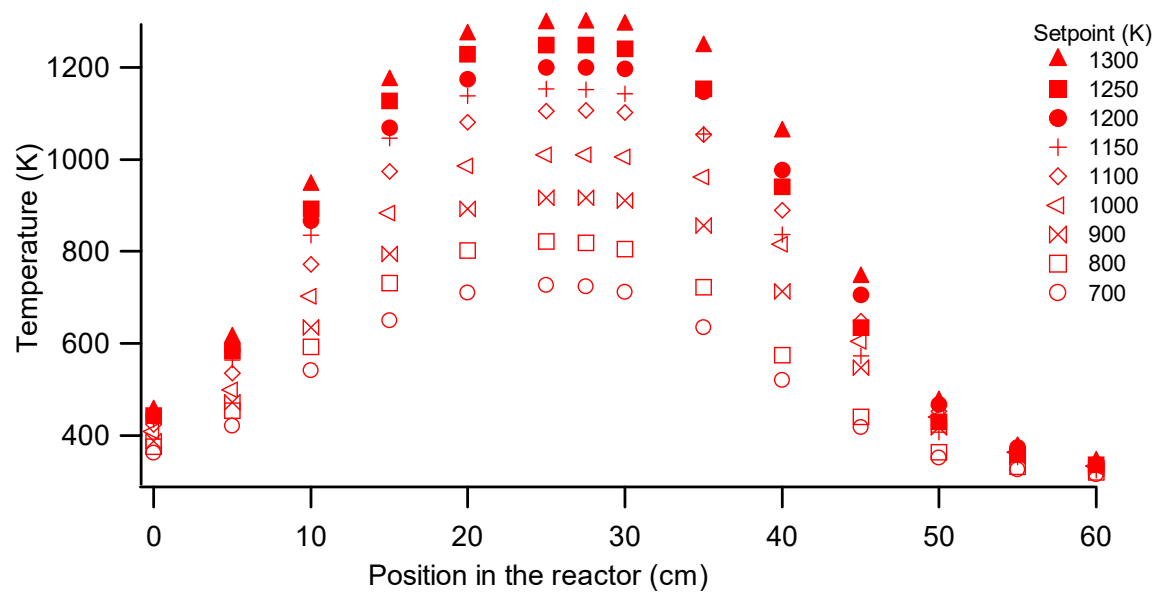

Figure 2: Measured temperature profiles in TR in the absence of reaction.

Simulations were performed assuming that the TR can be modeled as a PFR under our operating conditions (using the measured temperature profiles). This assumption has already been checked elsewhere [41].

\subsection{Jet-stirred reactor}

The spherical JSR (volume of $85 \mathrm{~cm}^{3}$ ), made of fused silica, is a type of ideal continuously stirred tank reactor which is well suited for gas phase kinetic studies. Reactants enter through an injection cross made of four nozzles which were located at its center. High turbulence was created 
by gas jets from the nozzles and led to homogeneity in composition. The isothermal JSR was preceded by a fused silica annular (ring-shaped) preheating zone in which the temperature of the gas was increased up to the reactor temperature allowing a homogenous gas phase temperature in the reactor. The residence time of the gas mixture inside the annular preheater was very short compared to its residence time inside the reactor (a few percents). Both the reactor and the preheating zone were heated by means of Thermocoax resistances rolled up around the reactor. The reaction temperature was measured at the center of the reacting gas phase by a K-type thermocouple located in a glass finger.

\subsection{Analytical procedure}

A heated transfer line maintained at $433 \mathrm{~K}$ was used to avoid product condensation between the reactor outlet and the analytical devices. The gases leaving the reactors were then analyzed using:

Gas chromatography (GC): a chromatograph (fitted with a PlotQ capillary column) a thermal conductivity detector (TCD) and a flame ionization detector (FID), was used for the quantification of light products and the reactant. The identification of reaction products was performed using a gas chromatograph equipped with a plotQ capillary column and coupled to a mass spectrometer. Response factors were determined by injecting calibration mixtures or using the effective carbon number method. Relative uncertainties in mole fractions were estimated to be $\pm 5 \%$ for species which were calibrated using standards and $\pm 10 \%$ for other ones.

A Fourier Transform Infrared gas analyzer (FTIR) from Thermo Scientific Antaris equipped with a Mercure Cadmium Tellure photoelectric detector was used to identify and quantify $\mathrm{CH}_{2} \mathrm{O}, \mathrm{CO}$, $\mathrm{H}_{2} \mathrm{O}, \mathrm{HCN}, \mathrm{NO}, \mathrm{CO}_{2}$ and $\mathrm{CH}_{3} \mathrm{OH}$. FTIR calibrations were obtained by injecting standards. A typical FTIR spectrum obtained during nitromethane pyrolysis is shown in Figure $\mathrm{S} 1$ in the supplementary material. Relative uncertainties were slightly higher than in GC since interferences may occur between bands of absorbing species.

\section{Kinetic mechanism}

The mechanism proposed here extends our recent work [31], which was developed to predict $\mathrm{CH}_{3} \mathrm{OH}$ and $\mathrm{C}_{2} \mathrm{H}_{5} \mathrm{OH}$ oxidation and $\mathrm{NO}_{\mathrm{x}}$ chemistry interaction. The present model also takes into account $\mathrm{NH}_{3}$ as fuel. The mechanism of Shrestha et al. [31] was validated for other $\mathrm{C}_{1}-\mathrm{C}_{2}$ fuels as well (methane $\left(\mathrm{CH}_{4}\right)$, acetylene $\left(\mathrm{C}_{2} \mathrm{H}_{2}\right)$, ethylene $\left(\mathrm{C}_{2} \mathrm{H}_{4}\right)$ and ethane $\left.\left(\mathrm{C}_{2} \mathrm{H}_{6}\right)\right)$ for a wide range of experimental conditions as available from the literature. We have demonstrated that the model captures $\mathrm{C}_{1}-\mathrm{C}_{2}$ hydrocarbon/oxygenated $\mathrm{NO}_{\mathrm{x}}$ chemistry interaction as well as $\mathrm{NO}$ formation in $\mathrm{C}_{1}-\mathrm{C}_{2}$ premixed flames. The here developed mechanism is based on published literature and the $\mathrm{NO}_{\mathrm{x}}$ sub-mechanism is augmented to include cross-reactions between nitrogen and carbon species. The main aim of this work is to include the $\mathrm{CH}_{3} \mathrm{NO}_{2}$ species as fuel molecule and to extend the validation range of our nitrogen chemistry. The nitromethane sub-mechanism includes $\mathrm{CH}_{3} \mathrm{NO}_{2}, \mathrm{CH}_{2} \mathrm{NO}_{2}, \mathrm{CH}_{3} \mathrm{ONO}, \mathrm{CH}_{3} \mathrm{NO}, \mathrm{CH}_{2} \mathrm{NO}, \mathrm{CH}_{3} \mathrm{NH}_{2}, \mathrm{CH}_{3} \mathrm{NH}, \mathrm{CH}_{2} \mathrm{NH}_{2}, \mathrm{CH}_{2} \mathrm{NH}$, and $\mathrm{HCNH}$ species and their related chemistry. Among them, $\mathrm{CH}_{3} \mathrm{NO}_{2}, \mathrm{CH}_{2} \mathrm{NO}_{2}, \mathrm{CH}_{3} \mathrm{ONO}$, and $\mathrm{CH}_{3} \mathrm{NO}$ are already 
included in our recently published mechanism [31]. However, for CH3NO the complete set of decomposition reactions were not included in [31], different to this work. Further, six additional nitrogen containing species (and their related reactions) were considered in this work, namely $\mathrm{CH}_{2} \mathrm{NO}, \mathrm{CH}_{3} \mathrm{NH}_{2}, \mathrm{CH}_{3} \mathrm{NH}, \mathrm{CH}_{2} \mathrm{NH}_{2}, \mathrm{CH}_{2} \mathrm{NH}$, and $\mathrm{HCNH}$. The inclusion of these species and their reactions have required updates. The complete reaction mechanism (CHEMKIN format) is provided in the supplementary material (SM).

A detailed description of the sub-mechanisms of the additional species, which are included in the present nitrogen chemistry, and the adaptation of the rate parameters are explained below highlighting the important reactions and their kinetics. The reactions and related rate parameters are mostly adopted from the work of Dean and Bozzelli [42].

\subsection{Brief overview of recent work on the thermal decomposition of $\mathrm{CH}_{3} \mathrm{NO}_{2}$}

As mentioned above, the mechanism proposed in this work is an extension of our recent work [31], and parts of the nitromethane sub-mechanisms are already included in that work. For the broad range of experimental conditions studied here, it was found that the unimolecular thermal dissociation reaction of $\mathrm{CH}_{3} \mathrm{NO}_{2}\left(\mathrm{CH}_{3} \mathrm{NO}_{2}(+\mathrm{M}) \rightleftharpoons \mathrm{CH}_{3}+\mathrm{NO}_{2}(+\mathrm{M})\right)$ is the reaction that exhibits the highest sensitivity (see also Section 4). The adopted rate parameters of this and other reactions in the $\mathrm{CH}_{3} \mathrm{NO}_{2}$ sub-mechanism are discussed in detail in our recent work [31]. However, in [31], several recent studies on the thermal $\mathrm{CH}_{3} \mathrm{NO}_{2}$ decomposition were not taken into account. In these studies [23,25,43-45], it was suggested that $\mathrm{CH}_{3} \mathrm{NO}_{2}$ not only thermally dissociates to $\mathrm{CH}_{3}+\mathrm{NO}_{2}$ but also isomerizes to methyl nitrate $\left(\mathrm{CH}_{3} \mathrm{ONO}\right)$ via a roaming type transition state finally dissociating to $\mathrm{CH}_{3} \mathrm{O}+\mathrm{NO}$. In 2009, Zhu and Lin [43] studied the $\mathrm{CH}_{3} \mathrm{NO}_{2}$ decomposition theoretically and suggested that the channel to $\mathrm{CH}_{3} \mathrm{O}+\mathrm{NO}$ could be detected in experiments. Later, Homayoon and Bowman [44] came to similar conclusions in their density functional theory (DFT) based theoretical analysis. However, both studies did not provide information about the conditions under which these products are formed. These were identified by Zhu et al. [45] suggesting that the roaming channel is active at pressures lower than 2 Torr over a wide temperature range (400-3000 K). This finding was confirmed by the succeeding study of Annesley et al. [23] who also performed shock tube experiments. Their theoretical analysis suggested that at pressures above 2 Torr the product distribution undergoes a sharp transition from the roaming dominated $\left(\mathrm{CH}_{3} \mathrm{ONO} \rightarrow \mathrm{CH}_{3} \mathrm{O}+\mathrm{NO}\right)$ to the bond-fission dominated $\left(\mathrm{CH}_{3}+\mathrm{NO}_{2}\right)$ channel. Hence the bond fission channel is dominating for combustion environments featuring significantly higher pressures in agreement with all of the studies mentioned above and the studies that were reviewed in our recent work [31]. Furthermore, this finding is supported by the later study of Matsugi and Shiina [25] proposing branching ratios of 0.97 and 0.03 in favor of the $\mathrm{C}-\mathrm{N}$ bond fission channel. Despite its low branching ratio, it is clearly recommended to take into account the roaming type channel in kinetic modeling studies [46]. Therefore, in the present work, we have included this channel using the rate parameters proposed by Matsugi and Shiina [25]. The available kinetic data on the dominating C-N fission channel are summarized in Figure S24 for low and high pressure conditions (see Supplementary material). The rate constant used in this work is adopted from [22], complemented with the results of [26] and well within the range of 
available literature data. This choice is supported by the recent studies of Matsugi and Shiina [25] and Vlasov et al. [46] and leads to fractions of the roaming type channel from 0.02 to 0.04 , increasing with temperature for the conditions studied in this work.

\section{2. $\mathrm{CH}_{3} \mathrm{NO}$ and $\mathrm{CH}_{2} \mathrm{NO}$ sub-mechanisms}

Only four reactions related to $\mathrm{CH}_{3} \mathrm{NO}$ were included and described in the recent work of Shrestha et al. [31], which are $\mathrm{CH}_{3} \mathrm{NO}_{2}+\mathrm{H} \leftrightharpoons \mathrm{CH}_{3} \mathrm{NO}+\mathrm{OH}, \mathrm{CH}_{3}+\mathrm{HNO} \leftrightharpoons \mathrm{CH}_{3} \mathrm{NO}+\mathrm{H}, \mathrm{CH}_{3}+\mathrm{HNO} \leftrightharpoons \mathrm{CH}_{4}+\mathrm{NO}$ and $\mathrm{CH}_{3}+\mathrm{NO}(+\mathrm{M}) \leftrightharpoons \mathrm{CH}_{3} \mathrm{NO}(+\mathrm{M})$. Furthermore, the $\mathrm{CH}_{3} \mathrm{NO} \mathrm{H}$-atom abstraction reactions with $\mathrm{H}$ and $\mathrm{O}$-atoms form $\mathrm{OH}, \mathrm{CH}_{3}$ and $\mathrm{NH}_{2}$ radicals with $\mathrm{CH}_{2} \mathrm{NO}$ as the main complementary product. However, the reactions $\mathrm{CH}_{3} \mathrm{NO}+\mathrm{O}$ (a) and $\mathrm{CH}_{3} \mathrm{NO}+\mathrm{OH}$ (b) are multi-channel reactions, with $\mathrm{CH}_{3}+\mathrm{NO}_{2}$ as the second channel for (a) and $\mathrm{CH}_{3}+\mathrm{HONO}$ for (b). The formed $\mathrm{CH}_{2} \mathrm{NO}$ from the above process can thermally decompose to $\mathrm{HNCO}+\mathrm{H}$. Furthermore, $\mathrm{CH}_{2} \mathrm{NO}$ can react with $\mathrm{H}$ - and $\mathrm{O}$-atoms as well as $\mathrm{OH}, \mathrm{CH}_{3}$, and $\mathrm{NH}_{2}$ radicals, which are also multichannel reactions. These are the $\mathrm{H}$-atom abstraction and the NO elimination. The common product of the $\mathrm{H}$-atom abstraction channel is HCNO, the specific products for NO elimination can be found in Table 2. In addition, $\mathrm{CH}_{2} \mathrm{NO}$ can also react with $\mathrm{O}_{2}$ to produce $\mathrm{CH}_{2} \mathrm{O}+\mathrm{NO}_{2}$. The reaction rate parameters of these reactions are adopted from the review of Dean and Bozzelli [42].

Table 2: NO elimination reactions from $\mathrm{CH}_{2} \mathrm{NO}$.

\begin{tabular}{ll}
\hline No. & Reaction \\
\hline 1. & $\mathrm{CH}_{2} \mathrm{NO}+\mathrm{H} \leftrightharpoons \mathrm{CH}_{3}+\mathrm{NO}$ \\
2. & $\mathrm{CH}_{2} \mathrm{NO}+\mathrm{O} \leftrightharpoons \mathrm{CH}_{2} \mathrm{O}+\mathrm{NO}$ \\
3. & $\mathrm{CH}_{2} \mathrm{NO}+\mathrm{OH} \leftrightharpoons \mathrm{CH}_{2} \mathrm{OH}+\mathrm{NO}$ \\
4. & $\mathrm{CH}_{2} \mathrm{NO}+\mathrm{CH}_{3} \leftrightharpoons \mathrm{C}_{2} \mathrm{H}_{5}+\mathrm{NO}$ \\
5. & $\mathrm{CH}_{2} \mathrm{NO}+\mathrm{NH}_{2} \leftrightharpoons \mathrm{CH}_{2} \mathrm{NH}_{2}+\mathrm{NO}$ \\
\hline
\end{tabular}

\section{3. $\mathrm{CH}_{3} \mathrm{NH}_{2}, \mathrm{CH}_{3} \mathrm{NH}$, and $\mathrm{CH}_{2} \mathrm{NH}_{2}$ sub-mechanisms}

$\mathrm{CH}_{3} \mathrm{NH}_{2}$ is mainly formed via the recombination reaction of $\mathrm{CH}_{3}$ and $\mathrm{NH}_{2}$ radicals, other products of $\mathrm{CH}_{3}$ and $\mathrm{NH}_{2}$ recombination are $\mathrm{CH}_{2}-3$ (triplet methylene radical) $+\mathrm{NH}_{3}, \mathrm{CH}_{2} \mathrm{NH}_{2}+\mathrm{H}$, $\mathrm{CH}_{3} \mathrm{NH}+\mathrm{H}$, and $\mathrm{CH}_{2} \mathrm{NH}+\mathrm{H}_{2}$. The rate parameters of these reactions are pressure dependent and are adopted from the work of Dean and Bozzelli [42], who calculated the rates using quantum Rice-Ramsperger-Kassel (QRRK) theory over the temperature range 600-2500 K. The formed $\mathrm{CH}_{3} \mathrm{NH}_{2}$ can thermally decompose to $\mathrm{CH}_{2} \mathrm{NH}$ and $\mathrm{H}_{2}\left(\mathrm{CH}_{3} \mathrm{NH}_{2}+\mathrm{M} \leftrightharpoons \mathrm{CH}_{2} \mathrm{NH}+\mathrm{H}_{2}+\mathrm{M}\right)$. The reaction rate is adopted from Zhang et al. [47], who calculated the rate constant using ab initio RiceRamsperger-Kassel-Marcus (RRKM) theory over the temperature range from 500 to $2000 \mathrm{~K}$. $\mathrm{CH}_{3} \mathrm{NH}_{2}$ can also undergo $\mathrm{H}$-atom abstraction reacting with $\mathrm{H}$ and $\mathrm{O}$-atoms, $\mathrm{OH}, \mathrm{CH}_{3}$ and $\mathrm{NH}_{2}$ radicals. The reaction product is $\mathrm{CH}_{2} \mathrm{NH}_{2}$ when the $\mathrm{H}$-atom is abstracted from a carbon-centered site. The common product is $\mathrm{CH}_{3} \mathrm{NH}$ when the abstraction takes place from the nitrogen-centered position. The respective complementary products are found in Table 3. The rate parameters of these H-atom abstraction channels are adopted from the work of Dean and Bozzelli [42], who 
estimated the values using the Direct hydrogen transfer (DHT) method based on the C-H and N-H bond dissociation energies (395 kJ/mol and $423 \mathrm{~kJ} / \mathrm{mol}$, respectively).

Table 3: $\mathrm{H}$-atom abstraction reactions from $\mathrm{CH}^{3} \mathrm{NH}^{2}$.

\begin{tabular}{ll}
\hline No. & Reaction \\
\hline 1. & $\mathrm{CH}_{3} \mathrm{NH}_{2}+\mathrm{H}=\mathrm{CH}_{2} \mathrm{NH}_{2}+\mathrm{H}_{2}$ \\
2. & $\mathrm{CH}_{3} \mathrm{NH}_{2}+\mathrm{H}=\mathrm{CH}_{3} \mathrm{NH}+\mathrm{H}_{2}$ \\
3. & $\mathrm{CH}_{3} \mathrm{NH}_{2}+\mathrm{O}=\mathrm{CH}_{2} \mathrm{NH}_{2}+\mathrm{OH}$ \\
4. & $\mathrm{CH}_{3} \mathrm{NH}_{2}+\mathrm{O}=\mathrm{CH}_{3} \mathrm{NH}+\mathrm{OH}$ \\
5. & $\mathrm{CH}_{3} \mathrm{NH}_{2}+\mathrm{OH}=\mathrm{CH}_{2} \mathrm{NH}_{2}+\mathrm{H}_{2} \mathrm{O}$ \\
6. & $\mathrm{CH}_{3} \mathrm{NH}_{2}+\mathrm{OH}=\mathrm{CH}_{3} \mathrm{NH}+\mathrm{H}_{2} \mathrm{O}$ \\
7. & $\mathrm{CH}_{3} \mathrm{NH}_{2}+\mathrm{CH}=\mathrm{CH}_{2} \mathrm{NH}+\mathrm{CH}_{4}$ \\
8. & $\mathrm{CH}_{3} \mathrm{NH}_{2}+\mathrm{CH}_{3}=\mathrm{CH}_{3} \mathrm{NH}+\mathrm{CH}_{4}$ \\
9. & $\mathrm{CH}_{3} \mathrm{NH}_{2}+\mathrm{NH}_{2}=\mathrm{CH}_{2} \mathrm{NH}+\mathrm{NH}_{3}$ \\
10. & $\mathrm{CH}_{3} \mathrm{NH}_{2}+\mathrm{NH}_{2}=\mathrm{CH}_{3} \mathrm{NH}+\mathrm{NH}_{3}$ \\
\hline
\end{tabular}

The formed $\mathrm{CH}_{2} \mathrm{NH}_{2}$ radical can thermally decompose to $\mathrm{CH}_{2} \mathrm{NH}$ and $\mathrm{H}\left(\mathrm{CH}_{2} \mathrm{NH}_{2} \leftrightharpoons \mathrm{CH}_{2} \mathrm{NH}+\mathrm{H}\right)$ or undergo $\mathrm{H}$-atom abstraction reacting with $\mathrm{H}$-atom and $\mathrm{O}$-atom, $\mathrm{OH}, \mathrm{CH}_{3}$ and $\mathrm{O}_{2}$. The $\mathrm{H}$-atom abstraction channel mainly yields the $\mathrm{CH}_{2} \mathrm{NH}$ radical. The rate parameters of these reactions are also adopted from the work of Dean and Bozzelli [42], where they performed QRRK calculations for temperatures ranging from 600 to $2500 \mathrm{~K}$ for the thermal decomposition of $\mathrm{CH}_{2} \mathrm{NH}_{2}$, while for the $\mathrm{H}$-atom abstraction the DHT approach was used. Reactions of $\mathrm{CH}_{2} \mathrm{NH}_{2}$ with $\mathrm{O}$-atoms as well as $\mathrm{OH}$ and $\mathrm{CH}_{3}$ radicals have other routes as forming $\mathrm{CH}_{2} \mathrm{O}+\mathrm{NH}_{2}, \mathrm{CH}_{2} \mathrm{OH}+\mathrm{NH}_{2}$, and $\mathrm{C}_{2} \mathrm{H}_{5}+\mathrm{NH}_{2}$, respectively. The rate parameters of these reactions are also adopted from Dean and Bozzelli [42], in analogy with the reactions $\mathrm{C}_{2} \mathrm{H}_{5}+\mathrm{O}, \mathrm{CH}_{3}+\mathrm{OH}$, and $\mathrm{CH}_{3}+\mathrm{C}_{2} \mathrm{H}_{5}$ respectively relying on the rate parameters from Baulch et al. [48]. Similarly, $\mathrm{CH}_{3} \mathrm{NH}$ formed in the above process can either thermally decompose to $\mathrm{CH}_{2} \mathrm{NH}$ and $\mathrm{H}\left(\mathrm{CH}_{3} \mathrm{NH} \leftrightharpoons \mathrm{CH}_{2} \mathrm{NH}+\mathrm{H}\right)$ or undergo $\mathrm{H}$-atom abstraction reacting with $\mathrm{H}$ and $\mathrm{O}$-atoms, $\mathrm{OH}$, and $\mathrm{CH}_{3}$ radicals mainly forming $\mathrm{CH}_{2} \mathrm{NH}$ and related products. The rate parameters of these reactions are again adopted from the work of Dean and Bozzelli [42]. For the thermal decomposition of $\mathrm{CH}_{2} \mathrm{NH}_{2}$, they performed QRRK calculations for temperatures between 600 and $2500 \mathrm{~K}$. The direct $\mathrm{H}$-atom abstraction parameters were derived with the DHT method. We note here that Dean and Bozzeli [42] concluded that thermal dissociation channels are more important than $\mathrm{H}$-atom abstraction channels.

\section{4. $\mathrm{CH}_{2} \mathrm{NH}$ and $\mathrm{HCNH}$ sub-mechanisms}

$\mathrm{CH}_{2} \mathrm{NH}$ is mainly formed from the thermal dissociation of $\mathrm{CH}_{3} \mathrm{NH}_{2}, \mathrm{CH}_{2} \mathrm{NH}_{2}$, and $\mathrm{CH}_{3} \mathrm{NH}$. The other formation channel of $\mathrm{CH}_{2} \mathrm{NH}$ is via the recombination of $\mathrm{CH}_{3}+\mathrm{NH}_{2}\left(\mathrm{CH}_{3}+\mathrm{NH}_{2} \leftrightharpoons \mathrm{CH}_{2} \mathrm{NH}+\mathrm{H}_{2}\right)$ and $\mathrm{CH}_{3}+\mathrm{NH}\left(\mathrm{CH}_{3}+\mathrm{NH} \leftrightharpoons \mathrm{CH}_{2} \mathrm{NH}+\mathrm{H}\right)$. Hydrogen atom abstraction from $\mathrm{CH}_{2} \mathrm{NH}$ can lead to two different radicals: $\mathrm{H}_{2} \mathrm{CN}$ and $\mathrm{HCNH}$. The $\mathrm{H}_{2} \mathrm{CN}$ radical is formed when the $\mathrm{H}$-atom is abstracted from the $\mathrm{N}$-atom, while abstraction from the $\mathrm{C}$-atoms leads to HCNH formation. The rate 
parameters of these multichannel reactions are adopted from the work of Dean and Bozzelli [42] and derived with the DHT method. The reaction of $\mathrm{CH}_{2} \mathrm{NH}$ with $\mathrm{O}$-atoms has another route yielding $\mathrm{CH}_{2} \mathrm{O}+\mathrm{NH}\left(\mathrm{CH}_{2} \mathrm{NH}+\mathrm{O} \leftrightharpoons \mathrm{CH}_{2} \mathrm{O}+\mathrm{NH}\right)$. This reaction is an exothermic reaction and the rate parameters are again adopted from Dean and Bozzelli [42] estimating the A-factor to be half of the value of the addition rate of $\mathrm{O}$-atom to ethylene $\left(\mathrm{O}+\mathrm{C}_{2} \mathrm{H}_{4}\right)$ and took the rate expression from Baulch et al. [49]. HCNH produced in the above process can thermally dissociate to $\mathrm{HCN}+\mathrm{H}$ $(\mathrm{HCNH} \leftrightharpoons \mathrm{HCN}+\mathrm{H})$. Dean and Bozzelli [42] performed a QRRK study for this reaction with $\mathrm{N}_{2}$ as bath gas over the temperature range $600-2000 \mathrm{~K}$ and proposed pressure dependent rate parameters, which were adopted in this work. Furthermore, the reaction of $\mathrm{HCNH}$ with $\mathrm{H}$-atoms is involved in two channels: one is the isomerization reaction ( $\mathrm{HCNH}+\mathrm{H} \leftrightharpoons \mathrm{H}_{2} \mathrm{CN}+\mathrm{H}$ ) and the second is the $\mathrm{H}$-atom abstraction $\left(\mathrm{HCNH}+\mathrm{H} \leftrightharpoons \mathrm{HCN}+\mathrm{H}_{2}\right)$. Dean and Bozzelli [42] determined the rate parameters of the reaction $\mathrm{HCNH}+\mathrm{H} \leftrightharpoons \mathrm{H}_{2} \mathrm{CN}+\mathrm{H}$ in analogy with $\mathrm{H}+\mathrm{C}_{2} \mathrm{H}_{5} \leftrightharpoons \mathrm{CH}_{3}+\mathrm{CH}_{3}$ and took half of the value proposed by Baulch et al. [48]. Dean and Bozzelli [42] estimated the H-atom abstraction channel $\left(\mathrm{HCNH}+\mathrm{H} \leftrightharpoons \mathrm{HCN}+\mathrm{H}_{2}\right)$ using the DHT method. The reaction of HCNH with $\mathrm{O}$-atoms is also a multichannel reaction producing $\mathrm{HNCO}+\mathrm{H}$ and $\mathrm{HCN}+\mathrm{OH}$ respectively. Dean and Bozzelli [42] estimated the reaction rate of the first reaction $\mathrm{HCNH}+\mathrm{O} \leftrightharpoons \mathrm{HNCO}+\mathrm{H}$ in analogy with the reaction $\mathrm{O}+\mathrm{C}_{2} \mathrm{H}_{5}$ whose rate expression is adopted from Baulch et al. [48]. For the direct $\mathrm{H}$-atom abstraction reaction $(\mathrm{HCNH}+\mathrm{O} \leftrightharpoons \mathrm{HCN}+\mathrm{OH})$, a DHT estimation was performed by Dean and Bozzelli [42]. $\mathrm{HCNH}$ reactions with $\mathrm{OH}$ and $\mathrm{CH}_{3}$ radicals are direct $\mathrm{H}$-atom abstractions giving $\mathrm{HCN}+\mathrm{H}_{2} \mathrm{O}$ and $\mathrm{HCN}+\mathrm{CH}_{4}$, whose rate parameters were estimated by Dean and Bozzelli [42] using the DHT method.

\subsection{Thermochemistry}

The thermochemistry of the species in the mechanism was presented in our recent work [31]. The thermochemistry of the six additional species $\left(\mathrm{CH}_{2} \mathrm{NO}, \mathrm{CH}_{3} \mathrm{NH}_{2}, \mathrm{CH}_{3} \mathrm{NH}, \mathrm{CH}_{2} \mathrm{NH}_{2}, \mathrm{CH}_{2} \mathrm{NH}\right.$, and $\mathrm{HCNH}$ ) has been adopted from Goos et al. [50], being available in Burcats thermochemical database [51].

\section{Results and discussion}

The $\mathrm{CH}_{3} \mathrm{NO}_{2} / \mathrm{NO}_{\mathrm{x}}$ model proposed in this work has been validated against a large set of experimental data, newly measured in the present work and taken from the literature. The validation targets include: speciation in flow and jet-stirred reactors, and premixed burner stabilized flames, laminar flame speeds and ignition delay times. This study investigates the $\mathrm{CH}_{3} \mathrm{NO}_{2} / \mathrm{NO}_{\mathrm{x}}$ kinetics in a multi set-up approach. In the figures shown below, the lines represent the simulation results using our proposed kinetic model and symbols represent the experimental data from the present work and the published literature unless stated differently. All simulations were performed using the LOGEresearch 1.10.0 [52] software package.

\subsection{Pyrolysis of nitromethane}




\subsubsection{Speciation in a flow reactor}

Figure 3, Figure 4 show the temperature dependence of species mole fractions in the reactive mixture during the pyrolysis experiment (inlet conditions: $\mathrm{CH}_{3} \mathrm{NO}_{2} 1 \% / \mathrm{He} 99 \%$ (on a mole basis)), residence time ( $\tau$ ) of $2.0 \mathrm{~s}$ ). The lines in the graph represent the predicted species profiles computed with the model developed in this work. It can be seen in Figure 3(a) that the fuel $\left(\mathrm{CH}_{3} \mathrm{NO}_{2}\right)$ consumption is very well captured by the model. However, at $1100 \mathrm{~K}$ (Figure 3(c)), $\mathrm{CO}$ and $\mathrm{CO}_{2}$ mole fractions are underpredicted by 33\%. It can be observed in Figure 3(b) that there is a large experimental scatter for $\mathrm{H}_{2} \mathrm{O}$ over the temperature range 850-1000 $\mathrm{K}$ and that the model underpredicts its mole fractions by $33 \%$. However, at $1100 \mathrm{~K}$, the model predicts mole fractions close to the experimental data. Water detection could be affected by condensation and/or adsorption in the tube preceding the FTIR cell, partly explaining the scatter observed for this species (despite the high dilution, water condensation could be possible in the short non heated part between the heated transfer line and the heated FTIR gas cell). The experimental trend for NO formation is well captured by the model. However, at $850 \mathrm{~K}$, the model predicts mole fractions $28 \%$ larger than the experimental ones, while at a higher temperature $(1100 \mathrm{~K})$ the overprediction is reduced to $15 \%$. It is interesting to see for $\mathrm{CH}_{2} \mathrm{O}$ (Figure 3(e)) that the model captures the experimental trend very well over the whole temperature range. The proposed model overpredicts $\mathrm{CH}_{2} \mathrm{O}$ by around $15 \%$ over the temperature range $975-1100 \mathrm{~K}$. Interestingly, the model is able to capture the small decrease in $\mathrm{CH}_{2} \mathrm{O}$ concentration around $875 \mathrm{~K}$. For the mole fraction of $\mathrm{CH}_{4}$ (Figure 3(f)), over the temperature range $700-925 \mathrm{~K}$, the model shows a decreasing trend of the $\mathrm{CH}_{4}$ mole fraction starting at $925 \mathrm{~K}$ whereas the experimental mole fractions reach a plateau. In Figure 4, it can be seen that the model overpredicts $\mathrm{C}_{2} \mathrm{H}_{6}$ by a factor of 3 , and underpredicts $\mathrm{CH}_{3} \mathrm{OH}$ and $\mathrm{HCN}$ by a factor of 3 and 8 respectively over the temperature range $1000-1100 \mathrm{~K}$.
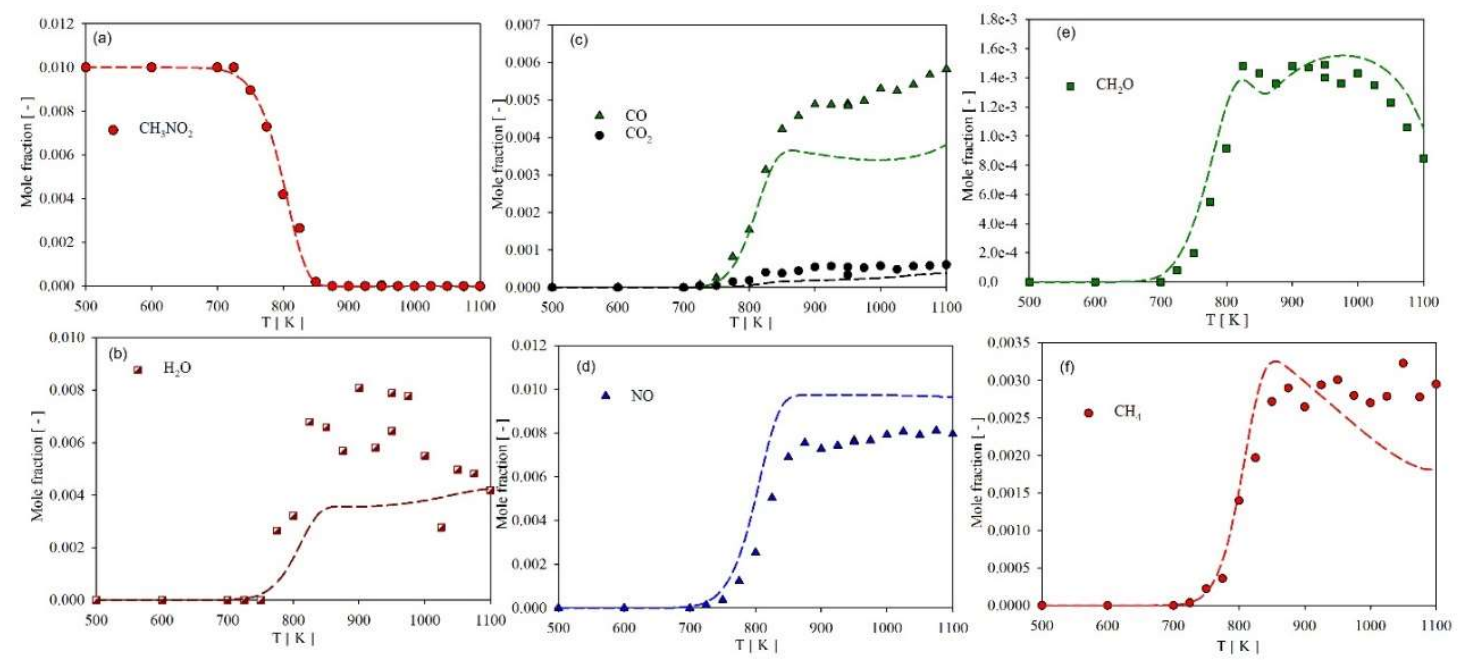

Figure 3: Pyrolysis of $\mathrm{CH}_{3} \mathrm{NO}_{2} 1 \% / \mathrm{He} 99 \%$ (on a mole basis) in a flow reactor at $1.07 \mathrm{bar}$, a residence time of $2.0 \mathrm{~s}$ in the isothermal zone of the reactor. Symbols: present work, dashed lines: data computed with the present model. 

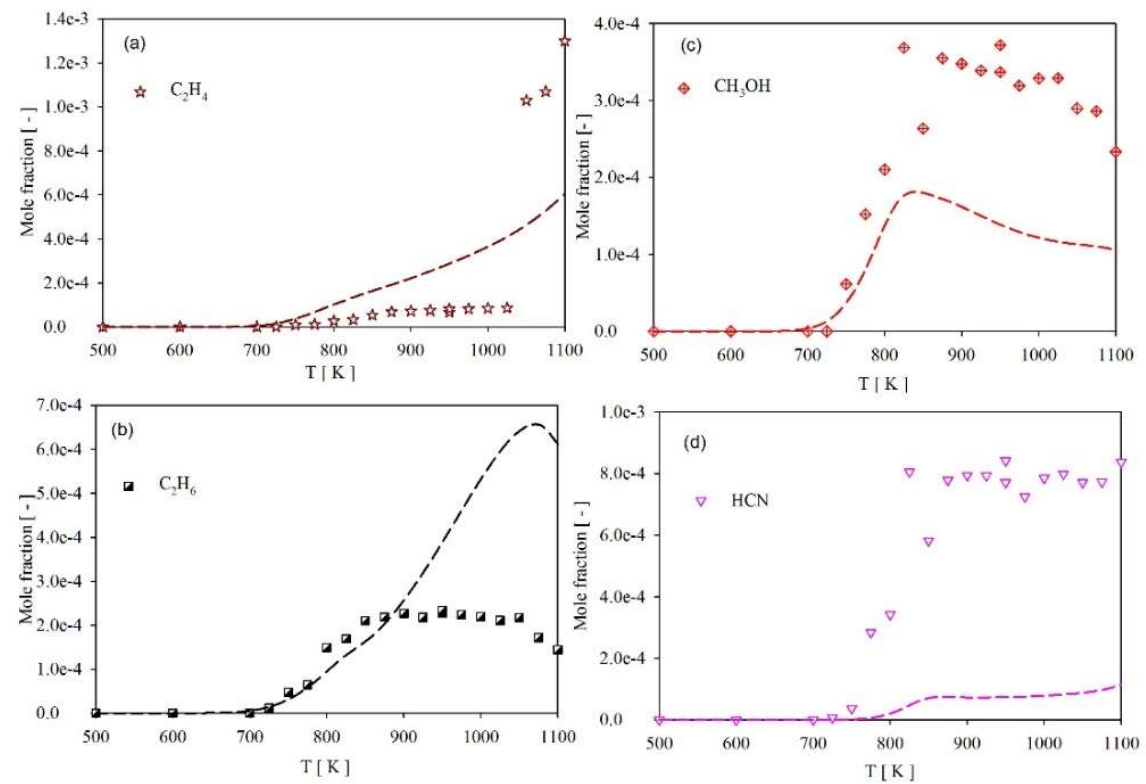

Figure 4: Pyrolysis of $\mathrm{CH}_{3} \mathrm{NO}_{2}(1 \% / \mathrm{He} 99 \%$, on a mole basis) in a flow reactor under the conditions of Figure 3. Symbols: present work, dashed lines: data computed with the present model.

Since the purpose of this work is to have a comprehensive model for both pyrolysis and oxidation, currently no attempt is made to optimize the model based on pyrolysis experimental data only. The model presented here performs much better under $\mathrm{CH}_{3} \mathrm{NO}_{2}$ oxidation conditions, which will be shown and discussed in Section 4.2 (Oxidation of nitromethane).

We now briefly discuss the reaction paths and the important reactions during $\mathrm{CH}_{3} \mathrm{NO}_{2}$ pyrolysis under the conditions of Figure 3 at $780 \mathrm{~K}$ (where $30 \%$ of $\mathrm{CH}_{3} \mathrm{NO}_{2}$ is consumed) with the help of the mass flux analysis shown in Figure 5 and the sensitivity analysis shown in Figure 6. In Figure 5 , black solid lines represent the integrated mass flux based on C-atoms and blue solid lines represent the integrated mass flux based on $\mathrm{N}$-atoms. Based on the nitrogen atom mass flux, $\mathrm{CH}_{3} \mathrm{NO}_{2}$ mainly decomposes $(\sim 62.5 \%)$ to $\mathrm{CH}_{3}$ and $\mathrm{NO}_{2}$ via a thermal dissociation channel $\left(\mathrm{CH}_{3} \mathrm{NO}_{2}(+\mathrm{M}) \leftrightharpoons \mathrm{CH}_{3}+\mathrm{NO}_{2}(+\mathrm{M})\right)$. Furthermore, $\sim 18.5 \%$ of $\mathrm{CH}_{3} \mathrm{NO}_{2}$ undergoes $\mathrm{H}$-atom abstraction reacting with $\mathrm{H}$-atoms, $\mathrm{OH}$, and $\mathrm{CH}_{3}$ radicals forming $\mathrm{CH}_{2} \mathrm{NO}_{2}$ and $\sim 11 \%$ react to $\mathrm{HNO}_{2}$ which completely isomerizes to $\mathrm{HONO}$. The $\sim 5 \% \mathrm{CH}_{3} \mathrm{NO}_{2}$ goes to $\mathrm{CH}_{3} \mathrm{NO}$, where the $\mathrm{H}$-atom abstraction is the only channel. The remaining fraction of $3 \%$ goes to $\mathrm{CH}_{3} \mathrm{O}+\mathrm{NO}$ via the another reaction channel $\mathrm{CH}_{3} \mathrm{NO}_{2} \leftrightharpoons \mathrm{CH}_{3} \mathrm{O}+\mathrm{NO}$ (not shown in Figure 5). This observation is in line with the sensitivity analysis shown in Figure 6 where the reaction $\mathrm{CH}_{3} \mathrm{NO}_{2}(+\mathrm{M}) \leftrightharpoons \mathrm{CH}_{3}+\mathrm{NO}_{2}(+\mathrm{M})$ shows the highest sensitivity and consecutively the $\mathrm{H}$-atom abstraction channel shows a much smaller sensitivity. Furthermore, $\mathrm{NO}_{2}$ produced from thermal dissociation of $\mathrm{CH}_{3} \mathrm{NO}_{2}$ is mainly converted to $\mathrm{NO}$, via reactions with $\mathrm{H}$-atom, $\mathrm{CH}_{3}$, and $\mathrm{HNO}$ radical. The reaction of $\mathrm{NO}_{2}$ with the $\mathrm{CH}_{3}$ radical $\left(\mathrm{CH}_{3}+\mathrm{NO}_{2} \leftrightharpoons \mathrm{CH}_{3} \mathrm{O}+\mathrm{NO}\right)$ has the highest contribution for converting $\mathrm{NO}_{2}$ to $\mathrm{NO}$ and this reaction is the second most sensitive reaction regarding the fuel decomposition (Figure 6). Then $\mathrm{CH}_{3} \mathrm{O}$, formed from the reaction $\mathrm{CH}_{3}+\mathrm{NO}_{2} \leftrightharpoons \mathrm{CH}_{3} \mathrm{O}+\mathrm{NO}$ and $\mathrm{CH}_{3} \mathrm{NO}_{2} \leftrightharpoons \mathrm{CH}_{3} \mathrm{O}+\mathrm{NO}$, thermally dissociates to produce $\mathrm{CH}_{2} \mathrm{O}$ and a $\mathrm{H}$-atom $\left(\mathrm{CH}_{3} \mathrm{O}(+\mathrm{M}) \leftrightharpoons \mathrm{CH}_{2} \mathrm{O}+\mathrm{H}(+\mathrm{M})\right)$. The formed $\mathrm{H}$-atom is mainly responsible for most of the $\mathrm{H}$-atom abstraction from $\mathrm{CH}_{3} \mathrm{NO}_{2}$. In line with this observation, the 
reaction $\left.\mathrm{CH}_{3} \mathrm{O}(+\mathrm{M}) \leftrightharpoons \mathrm{CH}_{2} \mathrm{O}+\mathrm{H}(+\mathrm{M})\right)$ is also one the most sensitive reactions of the nitromethane decomposition, appearing at third position (Figure 6). It can be seen in Figure 5 that the formed $\mathrm{CH}_{3} \mathrm{NO}, \mathrm{CH}_{2} \mathrm{NO}_{2}, \mathrm{NO}_{2}$, and $\mathrm{HONO}$ either thermally dissociate or react with radicals to give $\mathrm{NO}$ as the main product. This observation is in line with the NO concentration profile shown in Figure 3 (d) where the $\mathrm{NO}$ concentration is highest at higher temperatures and $\mathrm{CH}_{3} \mathrm{NO}_{2}$ (Figure 3(a)) is completely consumed in the same temperature region. The sensitivity analysis (Figure 6) also reveals that most of the sensitive reactions under these conditions are related to nitrogen chemistry.

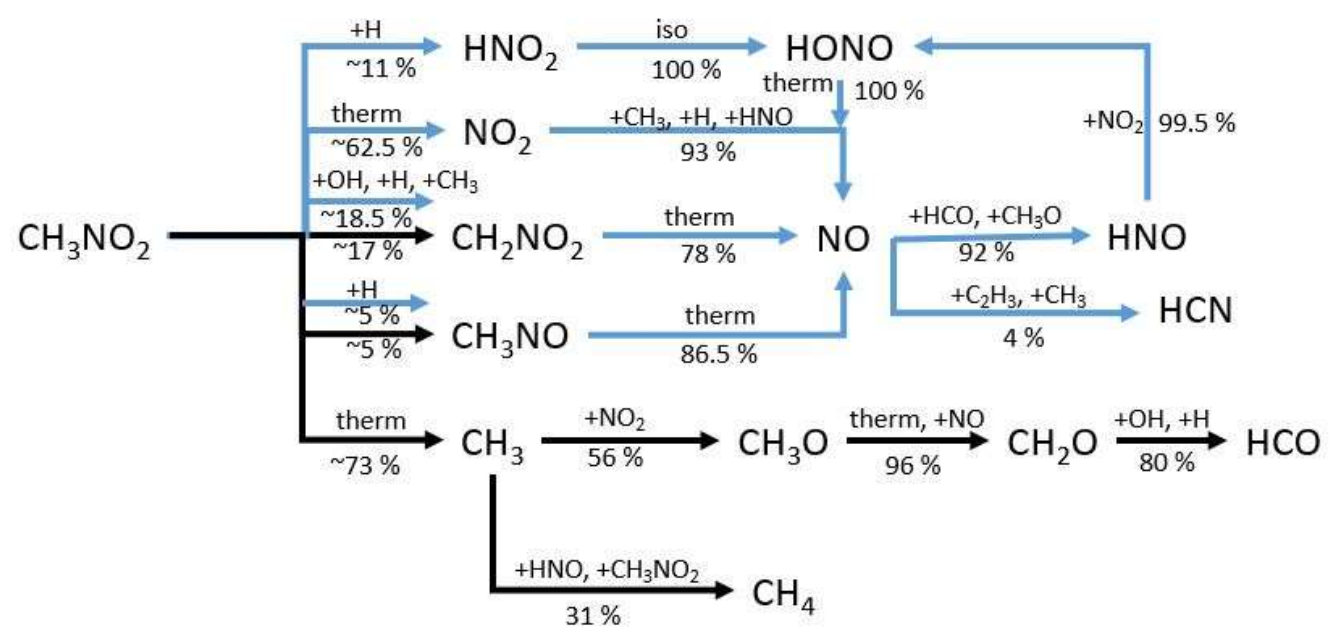

Figure 5: Reaction path analysis during $\mathrm{CH}_{3} \mathrm{NO}_{2} / \mathrm{He}$ pyrolysis for the conditions shown in Figure 3 at $780 \mathrm{~K}$. Blue lines (based on N-atom); black lines (based on C-atom). "therm" and "iso" in the figure mean thermal dissociation and isomerization, respectively.

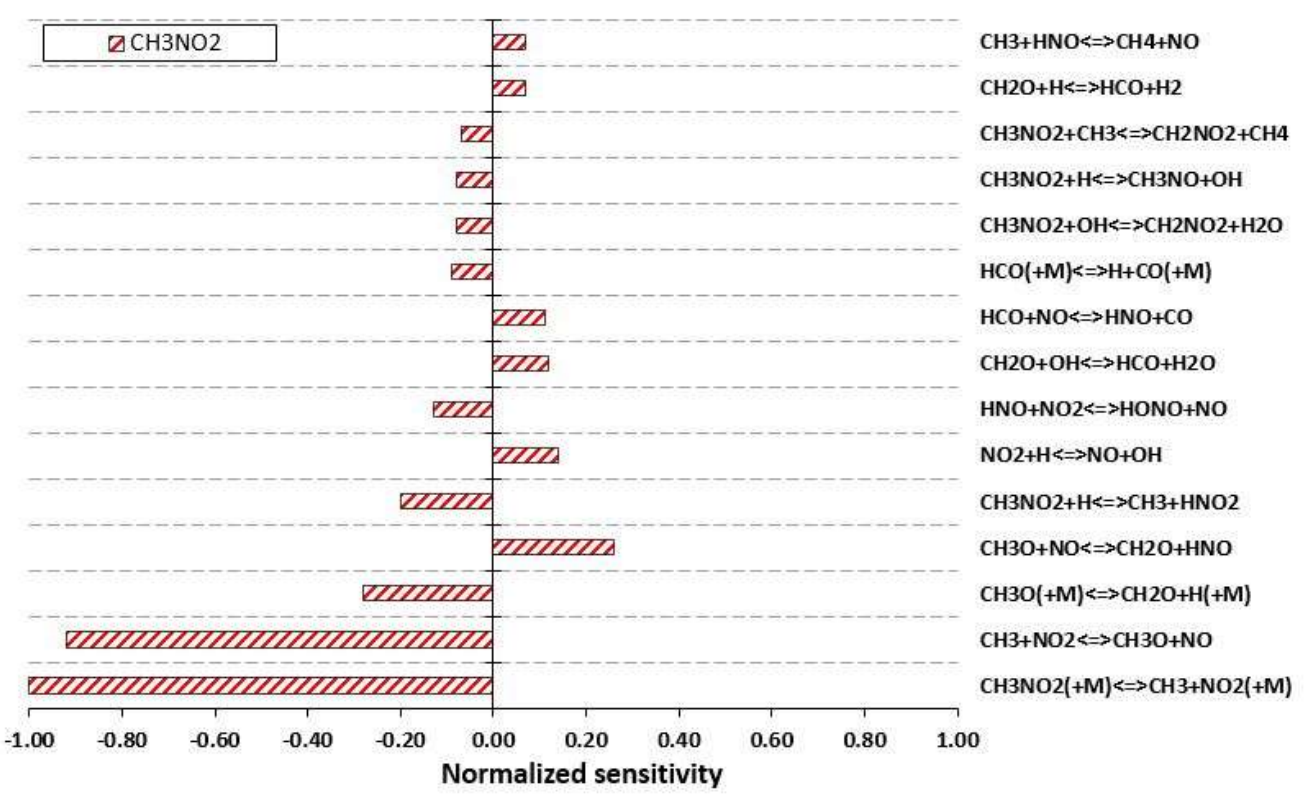

Figure 6: Sensitivity analysis during $\mathrm{CH}_{3} \mathrm{NO}_{2}$ / He pyrolysis for the conditions shown in Figure 3 at $780 \mathrm{~K}$ towards $\mathrm{CH}_{3} \mathrm{NO}_{2}$. 
To our best knowledge, there are no experimental data available in the literature for the oxidation of $\mathrm{CH}_{3} \mathrm{NO}_{2}$ in a flow reactor. Therefore, the model presented here is also validated against the published pyrolysis experimental data from the literature. Figure 7 shows the species profile for the pyrolysis of $\mathrm{CH}_{3} \mathrm{NO}_{2}$ (experimental conditions: $5 \% \mathrm{CH}_{3} \mathrm{NO}_{2} / 95 \%$ Ar at 5 Torr $(0.666 \mathrm{kPa})$ studied by Weng et al. [36] (symbols) over the temperature range 735-1475 K using tunable synchrotron vacuum ultraviolet photoionization and molecular-beam mass spectrometry. It can be observed in Figure 7(a) that the onset temperature of fuel consumption is well predicted by the model, which starts around $1000 \mathrm{~K}$. Further, the model is able to capture the experimental trend for the $\mathrm{CH}_{3} \mathrm{NO}_{2}$ decomposition over the whole temperature range. However, at higher temperatures $(\mathrm{T}>1200 \mathrm{~K})$, the model predicts the fuel decomposition onset at a temperature $50 \mathrm{~K}$ lower than observed in experiments. Moreover, for major species $\left(\mathrm{H}_{2} \mathrm{O}\right.$, and $\left.\mathrm{NO}\right)$, the model predictions against the experiment data are within reasonable uncertainty. At $1475 \mathrm{~K}$, the model overpredicts the NO mole fraction by $20 \%$ and underpredicts the $\mathrm{H}_{2} \mathrm{O}$ mole fraction by $50 \%$ respectively, while model significantly overpredicts $\mathrm{H}_{2}$ mole fraction, which is almost factor 3 higher at $1375 \mathrm{~K}$. For intermediate species like $\mathrm{NO}_{2}$, the model predictions agree well with the experiments. For $\mathrm{CH}_{2} \mathrm{O}$, the model overpredicts the experimental mole fractions by a factor of 4 , which is not consistent when compared to the results from our present study (see Figure 3(e)), where the model slightly overpredicts $\mathrm{CH}_{2} \mathrm{O}$ mole fractions at higher temperature, however still within the experimental uncertainty. It is worth noting that in both pyrolysis cases (Figure 3, Figure 7), $\mathrm{CH}_{2} \mathrm{O}$ is formed via the same reaction paths which are the thermal dissociation reactions of $\mathrm{CH}_{2} \mathrm{NO}_{2}\left(\mathrm{CH}_{2} \mathrm{NO}_{2} \leftrightharpoons \mathrm{CH}_{2} \mathrm{O}+\mathrm{NO}\right)$ and $\mathrm{CH}_{3} \mathrm{O}\left(\mathrm{CH}_{3} \mathrm{O}(+\mathrm{M}) \leftrightharpoons \mathrm{CH}_{2} \mathrm{O}+\mathrm{H}(+\mathrm{M})\right.$ ) (see Figures 5 and $\mathrm{S} 3$ in supplementary material). In fact, this over prediction of $\mathrm{CH}_{2} \mathrm{O}$ can be explained by the significantly higher contribution of reaction channel $\mathrm{CH}_{3} \mathrm{NO}_{2} \leftrightharpoons \mathrm{CH}_{3} \mathrm{O}+\mathrm{NO}$ forming $\mathrm{CH}_{3} \mathrm{O}$ (see Figure S3 in supplementary material) at lower pressure which further leads to $\mathrm{CH}_{2} \mathrm{O}+\mathrm{H}$ compared to case in Figure 3 (at 1.07 bar). Furthermore, in Figure 7(b), at $1475 \mathrm{~K}$, the model overpredicts the $\mathrm{CH}_{4}$ mole fraction by a factor of 2 but is in agreement for $\mathrm{CH}_{3}$ at this temperature. The model predicts an earlier formation of $\mathrm{CH}_{3}$ compared to experiments. The nitrogenated species HCNO and HNCO (Figure 7(d)) are significantly underpredicted by the model. The model suggests that $\mathrm{HCNO}$ is mainly formed via the reaction $\mathrm{CH}_{2}-3+\mathrm{NO} \leftrightharpoons \mathrm{HCNO}+\mathrm{H}$ and that $\mathrm{HNCO}$ is formed via the two reactions $\mathrm{CH}_{2} \mathrm{NO} \leftrightharpoons \mathrm{HNCO}+\mathrm{H}$ and $\mathrm{NCO}+\mathrm{CH}_{2} \mathrm{O} \leftrightharpoons \mathrm{HNCO}+\mathrm{HCO}$. At higher temperatures $(\mathrm{T}>1200 \mathrm{~K}$ ), although $\mathrm{HCNO}$ is within the experimental uncertainty, HNCO is still underpredicted by the model. Additional model validation for the pyrolysis of nitromethane is provided in the Supplementary material (see Figures S4-S6) where model predictions are good for major species but we see still have room for improvement for intermediate species predictions. Note that the use of tunable synchrotron vacuum ultraviolet photoionization and molecular-beam mass spectrometry allows Weng et al. [36] to detect species such as $\mathrm{CH}_{3}, \mathrm{HCNO}$, and HNCO, which cannot be observed by gas chromatography in our experimental study. 

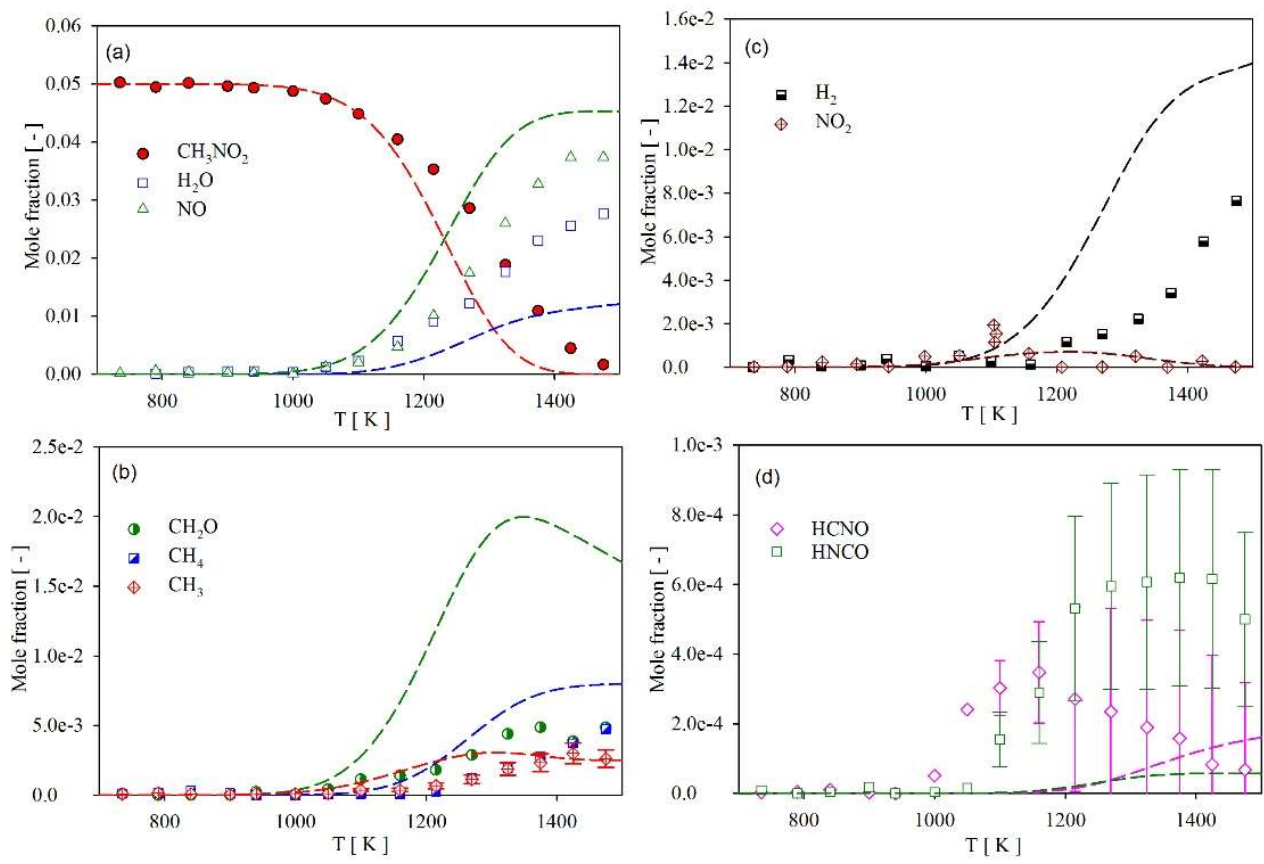

Figure 7: Pyrolysis of $\mathrm{CH}_{3} \mathrm{NO}_{2}$ 5\%/Ar 95\% (on a mole basis) in a flow reactor at 5 Torr $(0.666 \mathrm{kPa})$. Symbols: experimental data from Weng et al. [36]; dashed lines: this model. Error bars are only shown for $\mathrm{CH}_{3}, \mathrm{HCNO}$, and $\mathrm{HNCO}$ due to their much higher uncertainty compared to other species.

\subsubsection{Speciation in a jet-stirred reactor}

Figure 8 shows the species concentration vs temperature measured for the pyrolysis of $\mathrm{CH}_{3} \mathrm{NO}_{2}$ (experimental conditions: $1 \% \mathrm{CH}_{3} \mathrm{NO}_{2} / 99 \% \mathrm{He}$ (on a mole basis) in a JSR at $\tau=2.0 \mathrm{~s}$ ). Figure $8(\mathrm{a})$ shows that the fuel $\left(\mathrm{CH}_{3} \mathrm{NO}_{2}\right)$ consumption is well captured by the model for the whole temperature range. The onset of fuel consumption is observed at a temperature of about $700 \mathrm{~K}$, similarly to what was observed in the PFR (Figure 3(a)). However, in the JSR, $\mathrm{CH}_{3} \mathrm{NO}_{2}$ is almost completely consumed at around $925 \mathrm{~K}$ (Figure 8(a)), whereas $\mathrm{CH}_{3} \mathrm{NO}_{2}$ is completely consumed at $850 \mathrm{~K}$ in the PFR (Figure 3(a)) despite having similar initial conditions. This interesting observation is briefly discussed below. In both reactors (PFR and JSR), the proposed model is able to capture these trends very well. Similar observations as for the PFR case can be found for the comparison of model predictions of the intermediate species formation $\left(\mathrm{CH}_{4}, \mathrm{C}_{2} \mathrm{H}_{4}, \mathrm{C}_{2} \mathrm{H}_{6}\right.$, and $\mathrm{CH}_{3} \mathrm{OH}$ in Figure 8) and the experimental data: where $\mathrm{CH} 4$ is overpredicted and $\mathrm{C}_{2} \mathrm{H}_{4}, \mathrm{C}_{2} \mathrm{H}_{6}$, and $\mathrm{CH}_{3} \mathrm{OH}$ are underpredicted. 

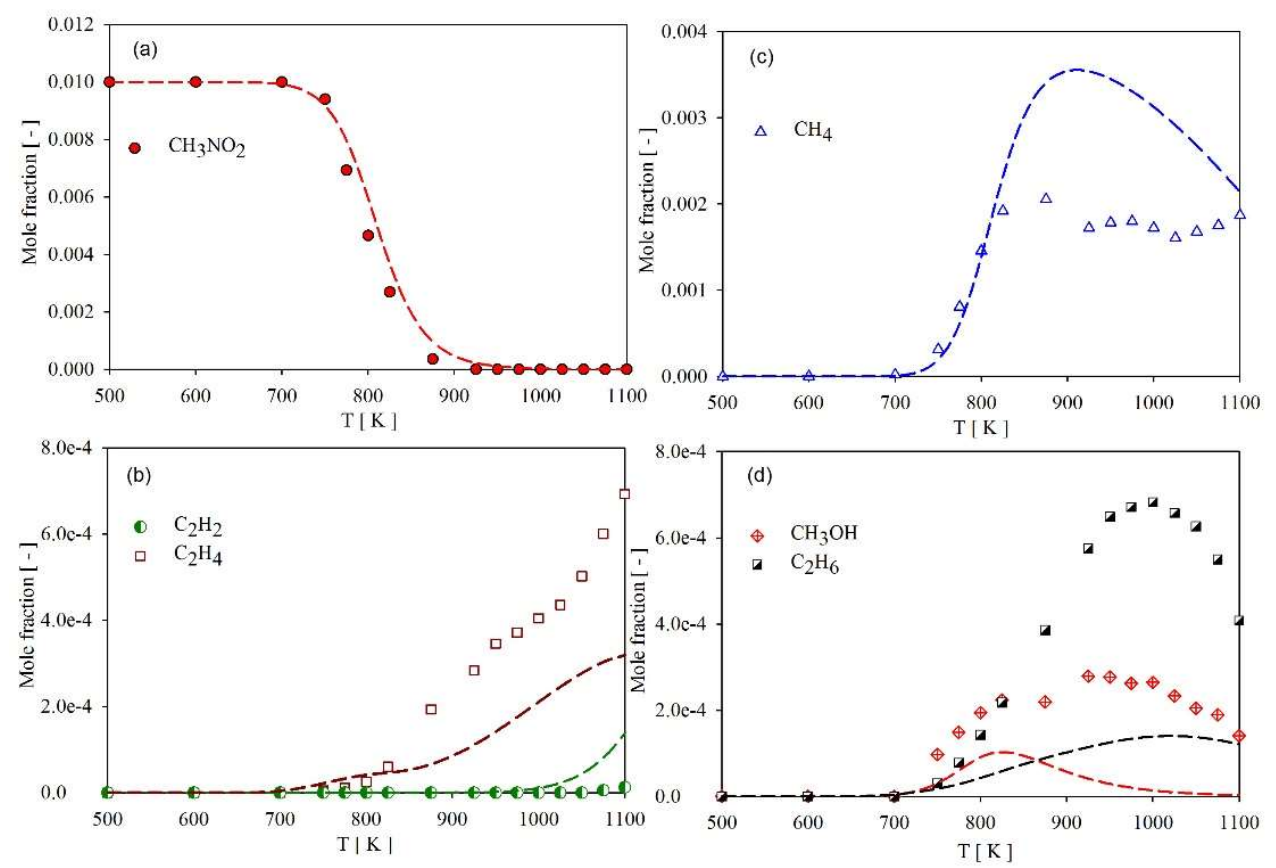

Figure 8: Pyrolysis of $\mathrm{CH}_{3} \mathrm{NO}_{2} 1 \% / \mathrm{He} 99 \%$ (on a mole basis) in a JSR at $1.07 \mathrm{bar}, \tau=2.0 \mathrm{~s}$.

Symbols: present work; dashed lines: this model.

A mass flux analysis (based on N-atoms, see Supplementary material Figure S7) reveals that the major pathways for the formation and consumption of the fuel, as well as intermediate species, remain the same in both reactors. In the case of the JSR, the thermal dissociation channel $\left(\mathrm{CH}_{3} \mathrm{NO}_{2}(+\mathrm{M}) \leftrightharpoons \mathrm{CH}_{3}+\mathrm{NO}_{2}(+\mathrm{M})\right)$ is slightly stronger (by $\left.\sim 9 \%\right)$ compared to the PFR case (Figure 5 ) and consecutively these $9 \%$ are compensated by the $\mathrm{H}$-atom abstraction channel becoming less important (see Figures 5 and S7 in supplementary material). Furthermore, it can be observed in the sensitivity analysis (Figure 9) that in the case of the JSR the most sensitive reaction is also the thermal dissociation reaction $\left(\mathrm{CH}_{3} \mathrm{NO}_{2}(+\mathrm{M}) \leftrightharpoons \mathrm{CH}_{3}+\mathrm{NO}_{2}(+\mathrm{M})\right)$. It can also be observed in Figure 9 that the sensitivity of the reaction $\mathrm{CH}_{3}+\mathrm{NO}_{2} \leftrightharpoons \mathrm{CH}_{3} \mathrm{O}+\mathrm{NO}$ is slightly lower (compared to the PFR case, in Figure 5) while still being the second most sensitive reaction. However, the majority of sensitive reactions appearing for the JSR (Figure 9) and PFR (Figure 6) cases remains the same despite slight changes in their order. To explain the higher consumption of $\mathrm{CH}_{3} \mathrm{NO}_{2}$ in a flow reactor at lower temperature compared to JSR conditions we analyze the profiles of important species (see Figure $\mathrm{S} 8$ in supplementary material for $\mathrm{CH}_{3} \mathrm{NO}_{2}$ concentration profile comparison). This early consumption is due to the fact that the $\mathrm{H}$-atom abstraction channel forming $\mathrm{HNO}_{2}$ $\left(\mathrm{CH}_{3} \mathrm{NO}_{2}+\mathrm{H} \leftrightharpoons \mathrm{CH}_{3}+\mathrm{HNO}_{2}\right)$ is more favored in a flow reactor compared to JSR conditions. $\mathrm{HNO}_{2}$ readily isomerizes to HONO which is therefore formed earlier in case of the flow reactor (see Figure S8 in supplementary material). HONO decomposes to the two reactive radicals $\mathrm{NO}$ and $\mathrm{OH}$. $\mathrm{NO}$ also reacts with the $\mathrm{HCO}$ radical to produce $\mathrm{HNO}+\mathrm{CO}$ and this reaction $(\mathrm{HCO}+\mathrm{NO} \leftrightharpoons \mathrm{HNO}+\mathrm{CO})$ has a higher sensitivity under flow reactor conditions. The HNO formed in this process reacts with $\mathrm{NO}_{2}$ mainly forming HONO (see Figure 5) leading to $\mathrm{NO}$ and $\mathrm{OH}$ formation via the same thermal decomposition path, adding more reactive radicals. Mole fraction profiles of $\mathrm{NO}$, and $\mathrm{NO}_{2}$ are also compared in Figure $\mathrm{S} 8$ in the supplementary material. In both the pyrolysis cases (JSR and PFR), the most sensitive reactions are part of the nitrogen chemistry. The 
model suggests that $\mathrm{H}$-atom abstraction reactions from $\mathrm{CH}_{3} \mathrm{NO}_{2}$ are contributing a lot to the pyrolysis chemistry of $\mathrm{CH}_{3} \mathrm{NO}_{2}$ under the conditions studied in this work.

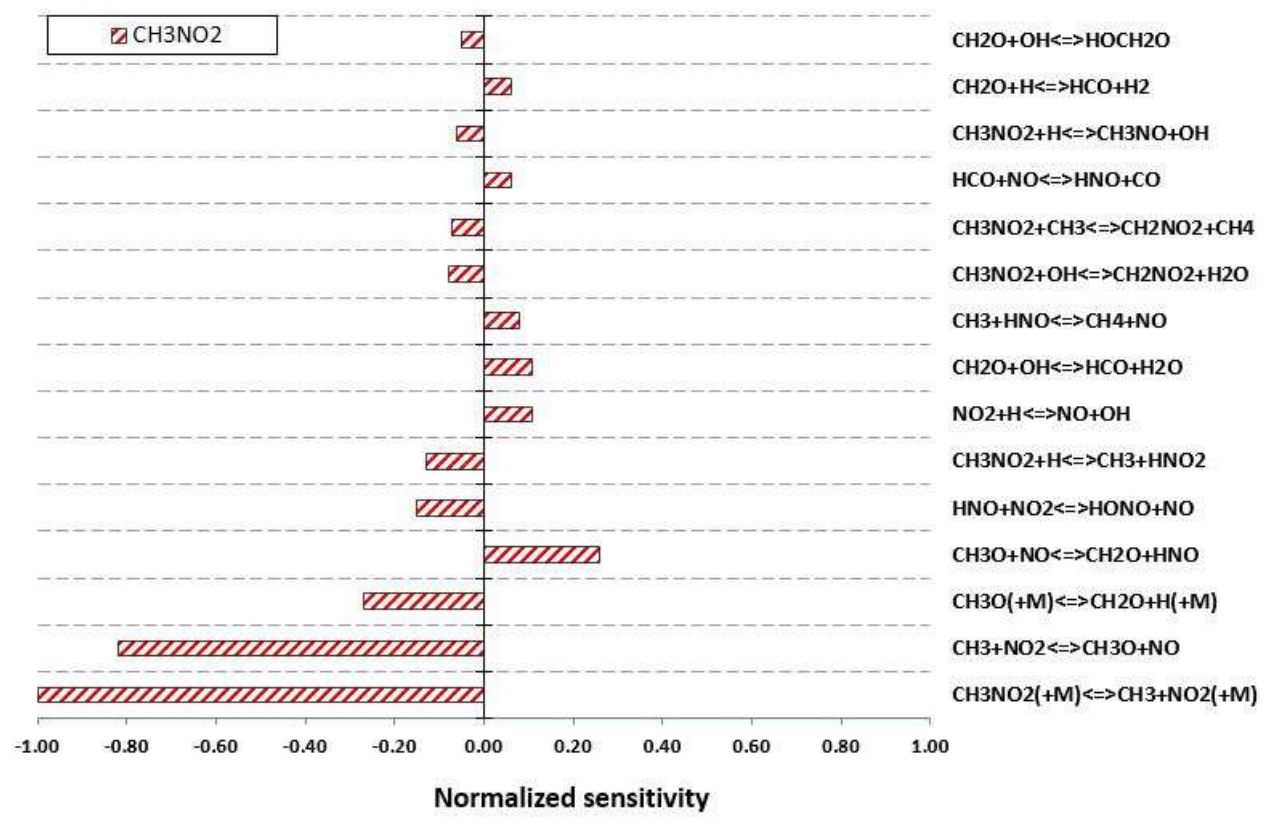

Figure 9: Sensitivity analysis during $\mathrm{CH}_{3} \mathrm{NO}_{2}$ / He pyrolysis for the condition shown in Figure 8 at $780 \mathrm{~K}$ towards $\mathrm{CH}_{3} \mathrm{NO}_{2}$.

Figure 10 shows the fuel $\left(\mathrm{CH}_{3} \mathrm{NO}_{2}\right)$ conversion during the pyrolysis of $\mathrm{CH}_{3} \mathrm{NO}_{2}$ (experimental conditions: $1 \% \mathrm{CH}_{3} \mathrm{NO}_{2} / 99 \% \mathrm{He}$ (on a mole basis) in the JSR at different residence times, at a pressure of 1.07 bar and a constant temperature of $775 \mathrm{~K}$ ). Symbols represent experimental data and the dashed line is for data computed using the model built in this study. It can be observed (in Figure 10) at $\tau=2.0 \mathrm{~s}$ that the model predicts a $10 \%$ lower conversion of the fuel. As the residence time increases $(\tau>2.0 \mathrm{~s})$, the difference between the measurements and model predictions gets smaller and at $\tau=7.0 \mathrm{~s}$, the model accurately predicts the experimental $\mathrm{CH}_{3} \mathrm{NO}_{2}$ conversion.

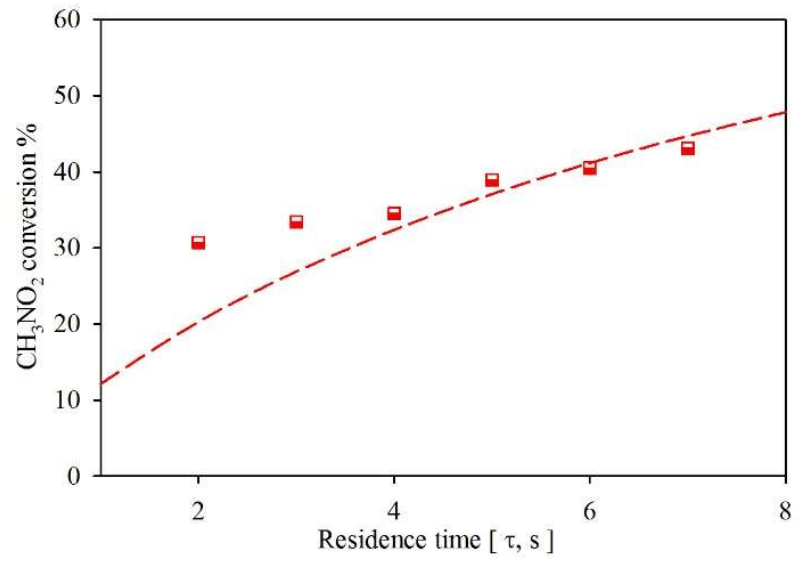

Figure 10: Conversion of $\mathrm{CH}_{3} \mathrm{NO}_{2}$ as a function of residence time during the pyrolysis of $\mathrm{CH}_{3} \mathrm{NO}_{2}$ 1\%/He 99\% (on a mole basis), $\mathrm{P}=1.07$ bar, $\mathrm{T}=775 \mathrm{~K}$ ). Symbols: present work; dashed lines: present model. 


\subsection{Oxidation of nitromethane}

\subsubsection{Speciation in a jet-stirred reactor}

Figure 11, Figure 12 show the evolution of species mole fractions with temperature during the oxidation of $\mathrm{CH}_{3} \mathrm{NO}_{2}$ (experimental conditions: see captions of Figure 11, Figure 12) in the JSR study by Weng et al. [36]. The experimental data (symbols) are compared against the model predictions (dashed lines). It can be observed in Figure 11(a) and (b) that the onset temperature of $\mathrm{CH}_{3} \mathrm{NO}_{2}$ and $\mathrm{O}_{2}$ consumption is well predicted by the model. However, for temperatures ranging from 780 to $850 \mathrm{~K}$, the model slightly underpredicts the $\mathrm{CH}_{3} \mathrm{NO}_{2}$ and $\mathrm{O}_{2}$ concentrations but the values are still within the experimental uncertainty (10\%). Further, it can be seen that for other major species ( $\mathrm{CO}, \mathrm{CO}_{2}, \mathrm{NO}$, and $\mathrm{H}_{2} \mathrm{O}$, Figure 11) the model is in good agreement with the experimental measurements. For $\mathrm{NO}_{2}$, the model captures the experimental trend very well and agrees with the $\mathrm{NO}_{2}$ peak concentration but it overpredicts the experimental values at most of the temperature points. Formation and consumption of nitrogenous intermediates species (HCN, HNO, and HONO) are well captured by the proposed model (Figure 12(a)). The model overpredicts $\mathrm{CH}_{3} \mathrm{OH}$ mole fractions (see Figure 12(b)), which is significantly underpredicted by the model for the case of pyrolysis (see Figure 4, Figure 8). Furthermore, the formation of $\mathrm{CH}_{2} \mathrm{O}$ (Figure 12(b)), which is the direct product of the thermal decomposition of $\mathrm{CH}_{2} \mathrm{NO}_{2}$ and $\mathrm{CH}_{3} \mathrm{O}$, is well captured by the model. Figure 12(c, d), shows that the model overpredicts the $\mathrm{CH}_{4}$ mole fraction and underpredicts $\mathrm{C}_{2} \mathrm{H}_{4}$ and $\mathrm{C}_{2} \mathrm{H}_{6}$ mole fractions at a higher temperature. The fuel decomposition pathways and the important reactions will be discussed with the help of mass flow analysis and sensitivity analysis to see the difference between pyrolysis and oxidation.
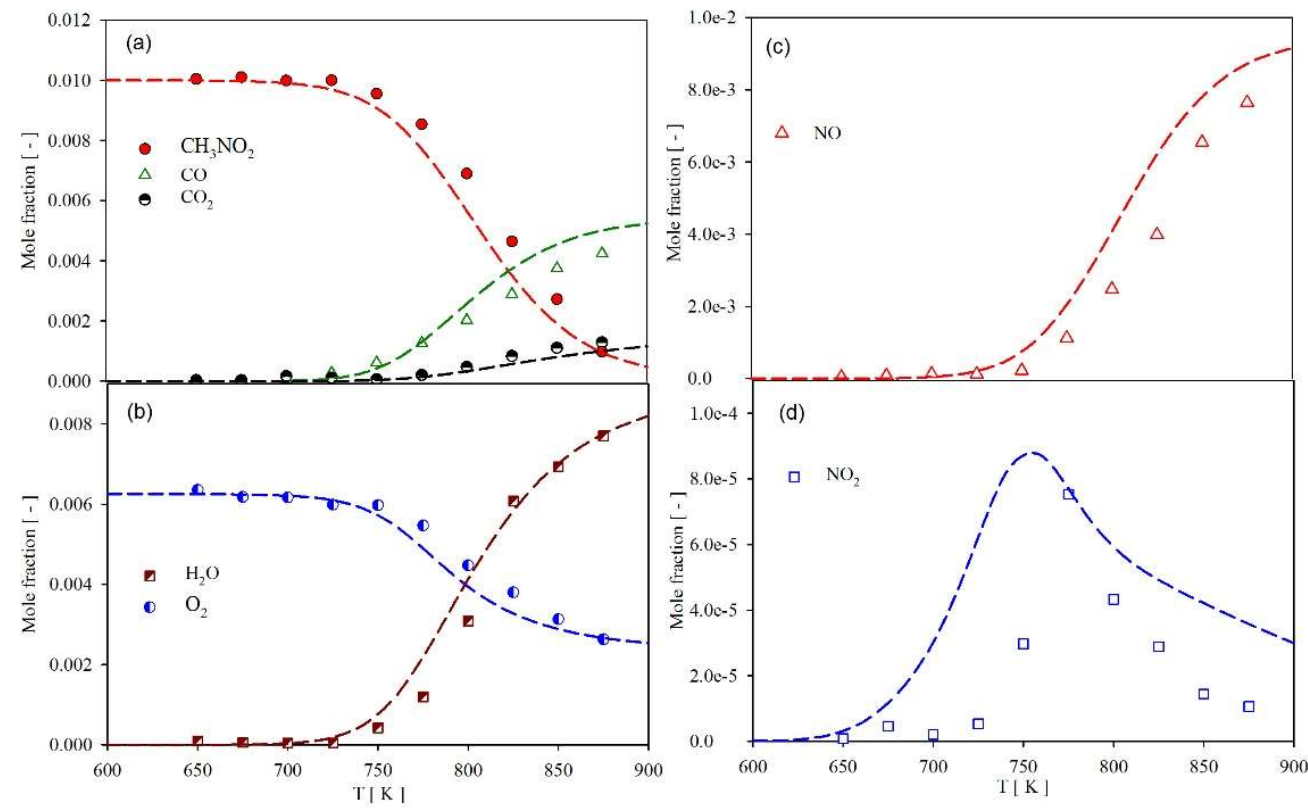

Figure 11: Oxidation of $\mathrm{CH}_{3} \mathrm{NO}_{2}\left(1 \% \mathrm{CH}_{3} \mathrm{NO}_{2} / \mathrm{O}_{2} 0.625 \% / \mathrm{Ar} 98.375 \%\right.$ at $\left.1 \mathrm{~atm}, \phi=2.0, \tau=2.0 \mathrm{~s}\right)$ in a JSR. Symbols: experimental data from Weng et al. [36]; dashed lines: present model. 


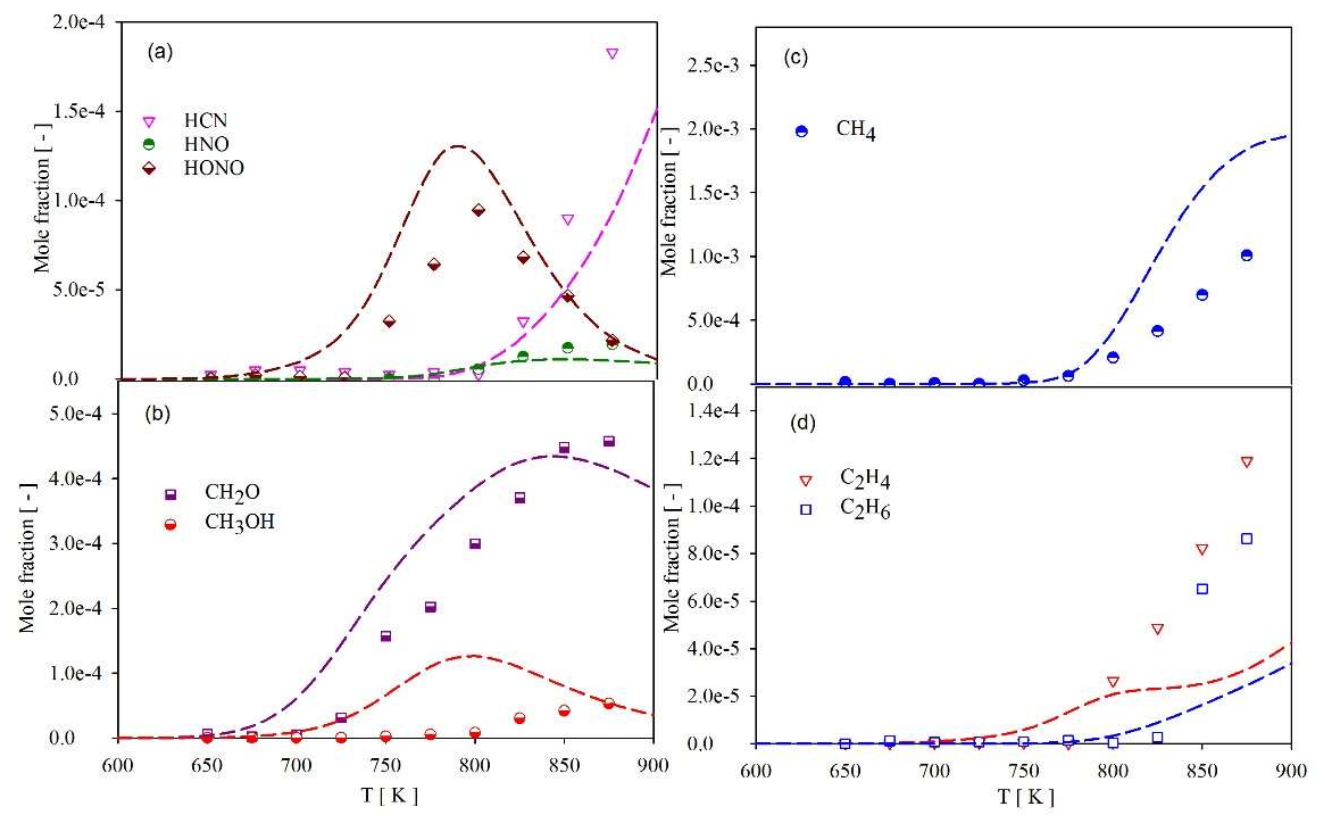

Figure 12: Oxidation of $\mathrm{CH}_{3} \mathrm{NO}_{2}\left(\mathrm{CH}_{3} \mathrm{NO}_{2} 1 \% / \mathrm{O}_{2}\right.$ 0.625\%/Ar 98.375\%) for conditions of Figure

11 in a JSR. Symbols: experimental data from Weng et al. [36]; dashed lines: present model.

Figure 13 shows the integrated mass flux analysis based on nitrogen atoms and Figure 14 shows the normalized sensitivity for the 15 most sensitive reactions towards $\mathrm{CH}_{3} \mathrm{NO}_{2}$ during the $\mathrm{CH}_{3} \mathrm{NO}_{2} / \mathrm{O}_{2} / \mathrm{Ar}$ oxidation in the JSR for the conditions shown in Figure 11 at $780 \mathrm{~K}$. It can be observed in Figure 13 that $\mathrm{CH}_{3} \mathrm{NO}_{2}$ is mainly decomposed via the thermal dissociation channel $\left(\mathrm{CH}_{3} \mathrm{NO}_{2}(+\mathrm{M}) \leftrightharpoons \mathrm{CH}_{3}+\mathrm{NO}_{2}(+\mathrm{M})\right)$. However, in the case of oxidation, thermal dissociation is weaker by $11 \%$ and the $\mathrm{H}$-atom abstraction channel forming $\mathrm{CH}_{2} \mathrm{NO}_{2}$ is stronger by $\sim 15 \%$ compared to pyrolysis conditions (see Figure S7 in supplementary material). The other minor channels forming $\mathrm{HNO}_{2}$ and $\mathrm{CH}_{3} \mathrm{NO}$ are less favored by $2 \%$ and $1 \%$ respectively compared to pyrolysis conditions (see Figure S7 in supplementary material). Furthermore, a small fraction $\sim 2.5 \%$ of $\mathrm{CH}_{3} \mathrm{NO}_{2}$ decomposes to $\mathrm{CH}_{3} \mathrm{O}+\mathrm{NO}$, similar to the pyrolysis case (Figure 8). However, the reaction path pattern for the formation and consumption of the major and intermediate species remains the same for both conditions. It can be observed in Figure 14 that the most sensitive reaction is the chain propagation channel $\mathrm{CH}_{3}+\mathrm{NO}_{2} \leftrightharpoons \mathrm{CH}_{3} \mathrm{O}+\mathrm{NO}$, followed by the thermal dissociation channel $\mathrm{CH}_{3} \mathrm{NO}_{2}(+\mathrm{M}) \leftrightharpoons \mathrm{CH}_{3}+\mathrm{NO}_{2}(+\mathrm{M})$ contrary to pyrolysis conditions (see Figure 9). During nitromethane oxidation, the third most sensitive reaction is $\mathrm{CH}_{3} \mathrm{NO}_{2}+\mathrm{OH} \leftrightharpoons \mathrm{CH}_{2} \mathrm{NO}_{2}+\mathrm{H}_{2} \mathrm{O}$ (Figure 14), which is in the 10th rank under pyrolysis conditions (Figure 9). This observation is in line with the flow analysis (Figure 13) where this path $\left(\mathrm{CH}_{3} \mathrm{NO}_{2}+\mathrm{OH} \leftrightharpoons \mathrm{CH}_{2} \mathrm{NO}_{2}+\mathrm{H}_{2} \mathrm{O}\right)$ is stronger by a factor of 2 compared to pyrolysis conditions (see Figure S7 in supplementary material). The reaction $\mathrm{CH}_{3} \mathrm{O}(+\mathrm{M}) \leftrightharpoons \mathrm{CH}_{2} \mathrm{O}+\mathrm{H}(+\mathrm{M})$ is also one of the most sensitive reactions since this reaction is mainly responsible for the formation of $\mathrm{H}$-atoms, which react with $\mathrm{NO}_{2}$ to give the $\mathrm{OH}$ radical $\left(\mathrm{NO}_{2}+\mathrm{H} \leftrightharpoons \mathrm{NO}+\mathrm{OH}\right)$. This reaction $\left(\mathrm{NO}_{2}+\mathrm{H} \leftrightharpoons \mathrm{NO}+\mathrm{OH}\right)$ contributes to $30 \%$ of $\mathrm{OH}$ formation, eventually influencing the radical pool in the system. The sensitivity analysis (Figure 14) shows that the $\mathrm{OH}$ radical takes part in most of the reactions and we, therefore, discuss other pathways forming $\mathrm{OH}: \mathrm{NO}+\mathrm{HO}_{2} \leftrightharpoons \mathrm{NO}_{2}+\mathrm{OH}$, which contributes by $30 \%$ to the $\mathrm{OH}$ formation and $27 \%$ contribution stems from the direct thermal 
dissociation of the HONO radical $(\mathrm{NO}+\mathrm{OH}(+\mathrm{M}) \leftrightharpoons \mathrm{HONO}(+\mathrm{M}))$. The thermal dissociation of HONO also gives $\mathrm{NO}$, which mainly forms $\mathrm{HNO}$ in reactions with $\mathrm{CH}_{3} \mathrm{O}, \mathrm{HCO}, \mathrm{HONO}$, and $\mathrm{HO}_{2}$ radicals. The formed $\mathrm{HNO}$ completely goes to $\mathrm{HONO}$ in the reaction with $\mathrm{NO}_{2}\left(\mathrm{HNO}+\mathrm{NO}_{2} \leftrightharpoons \mathrm{HONO}+\mathrm{NO}\right)$ and this reaction is the $8^{\text {th }}$ most sensitive reaction (Figure 14). It can be observed in the reaction flow analysis (Figure 13) that there is a small cycle where NO is continuously recycled back $(\mathrm{NO} \rightarrow \mathrm{HNO} \rightarrow \mathrm{HONO} \rightarrow \mathrm{NO}$ ) in the process forming reactive $\mathrm{OH}$ radicals.

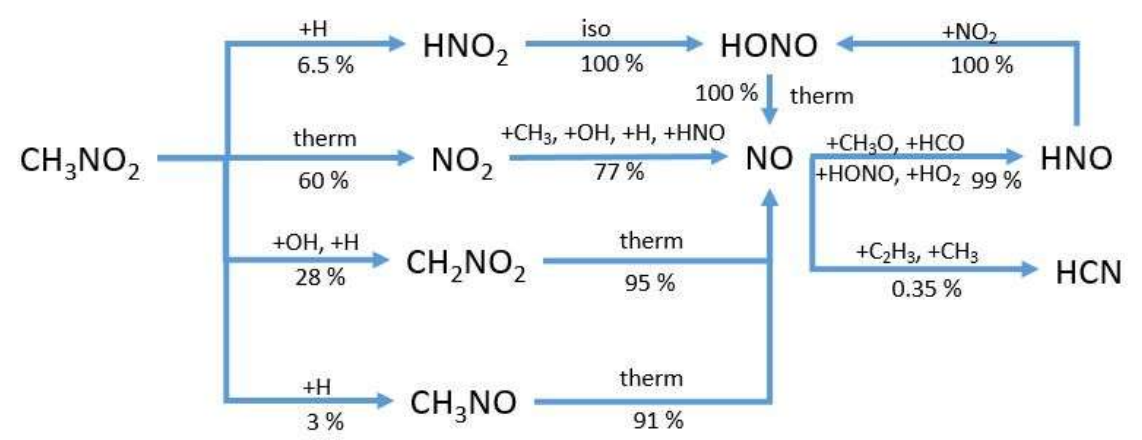

Figure 13: Major reaction paths during $\mathrm{CH}_{3} \mathrm{NO}_{2} 1 \% / \mathrm{O}_{2}$ 0.625\%/Ar $98.375 \%$ oxidation in a JSR for the conditions of Figure 11 at $780 \mathrm{~K}$ (based on N-atom). "therm" and "iso" in the figure mean thermal dissociation and isomerization, respectively.

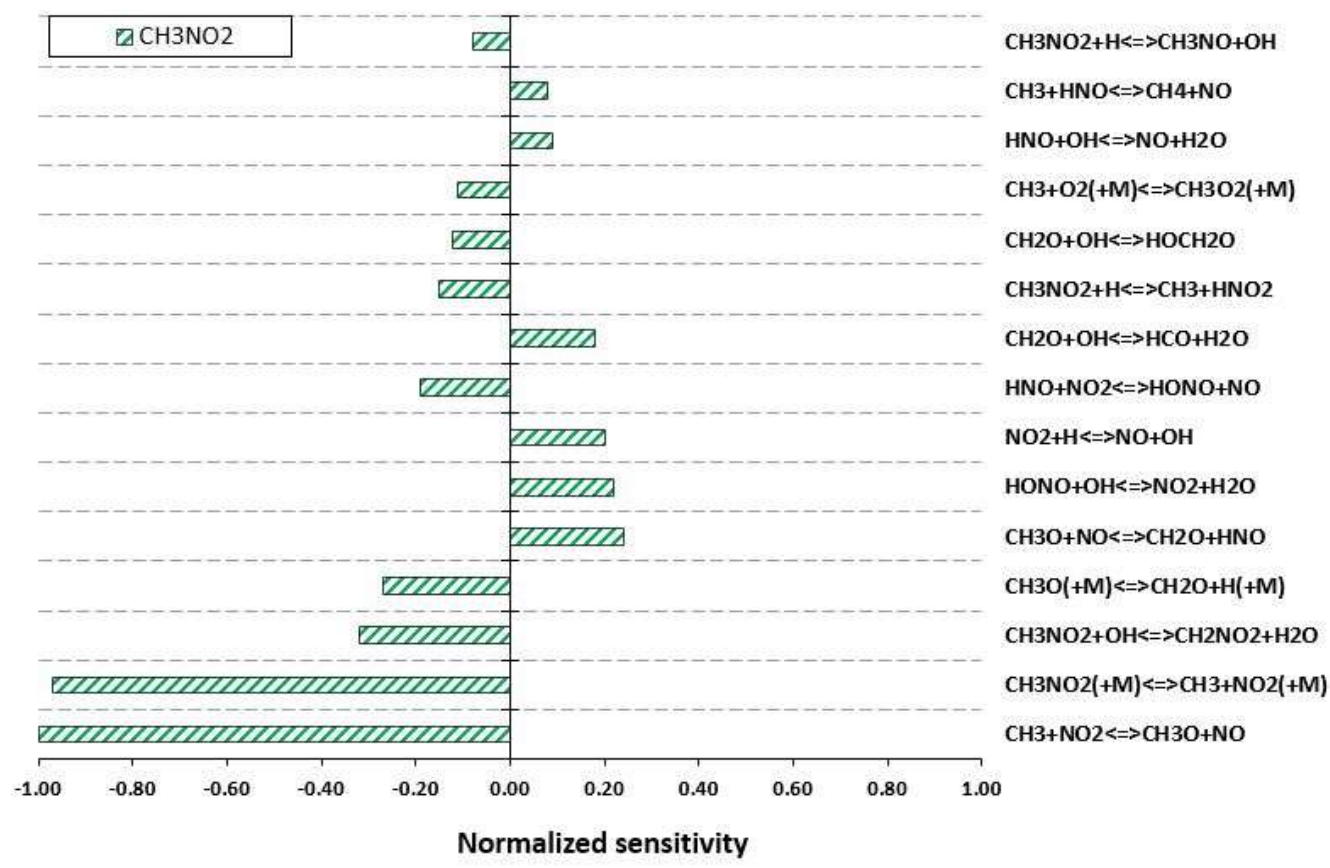

Figure 14: Sensitivity analysis during $\mathrm{CH}_{3} \mathrm{NO}_{2} / \mathrm{O}_{2} / \mathrm{Ar}$ oxidation in a JSR for the conditions of Figure 11 at $780 \mathrm{~K}$ towards $\mathrm{CH}_{3} \mathrm{NO}_{2}$.

It is worth noting at this point that ignition delay times for $\mathrm{CH}_{4} / \mathrm{CH}_{3} \mathrm{NO}_{2}$ blends were recently studied in a shock tube by Shang et al. [53] and they reported that $\mathrm{CH}_{3} \mathrm{NO}_{2}$ can dramatically reduce the ignition delay time of $\mathrm{CH}_{4}$, and the reduction effect increases with increasing blending ratio. This is due to the fact that with $\mathrm{CH}_{3} \mathrm{NO}_{2}$ in the system, the concentration of the radical pool 
increases (see discussion in the section on reaction pathway analysis in Shang et al. [53]). This finding from Shang et al. [53] is in line with the work of Jia et al. [35] who also observed that the addition of nitromethane greatly increases the conversion rate of $n$-decane. NO has been long used as an ignition/reactivity promoter [54] for hydrocarbons but detailed studies about the enhancement effect of $\mathrm{CH}_{3} \mathrm{NO}_{2}$ are scarce. Additional model validation for nitromethane oxidation in a JSR can be found in the Supplementary material (Figures S9-S11).

\subsubsection{Speciation in burner-stabilized flames}

Burner stabilized flames provide important information regarding the flame structure, species formation and consumption in the reaction zone and subsequently about emission formation pathways. Therefore, we give special attention to the speciation predictions for burner-stabilized flames. The diffusion of small radicals is the determining process for the flame structure in premixed flames. The radical species $\mathrm{O}, \mathrm{H}$ and $\mathrm{OH}$ are the most important species controlling the reactivity of the system during fuel oxidation.

For the burner-stabilized flame modeling, a mixture average transport model, thermal diffusion and radiative heat transfer were considered. The temperature profile is calculated solving the energy conservation equation, which considers the heat flux to the burner. We calculate the concentrations of all stable species on the burner surface from the gas composition in the feed, and the species diffusion close to the boundary. For all major radicals, we consider recombination at the burner surface. The undisturbed flame stabilizes above the burner through heat loss, which is calculated from the temperature gradient at the burner surface. The heat loss determines the maximum flame temperature, which is captured well.

Zhang et al. [39] experimentally studied a low-pressure (4.666 $\mathrm{kPa}$ ) $\mathrm{CH}_{3} \mathrm{NO}_{2} / \mathrm{O}_{2} / \mathrm{Ar}$ premixed burner stabilized flame at three different equivalence ratios $(\phi)$, namely 1.0, 1.5 and 2.0. Figure 15 , Figure 16 show species concentrations vs height above the burner ( $\mathrm{HAB}$ ) in a $\mathrm{CH}_{3} \mathrm{NO}_{2} / \mathrm{O}_{2} / \mathrm{Ar}$ flame at $\phi=1.5$ [39]. Calculations were performed imposing the experimental temperature profile (dashed lines), and by solving the energy conservation equation (solid lines). Comparison between the measured and calculated temperature profiles is shown in the Supplementary material of this work (Figure S12). The difference in the calculated and experimental temperature profiles is observed mainly in the post-flame zone where it is governed by the thermochemistry and radiative heat loss. To reduce the over prediction of the calculated temperature in the postflame zone, the radiation loss needs to be increased by a factor of 8 as shown in Figure S12. This was done because we cannot quantify the heat loss in post flame zone from other possible sources (e.g cooling due to thermocouple) and we use an increased radiative heat loss to account for such effects. It can be observed in Figure 15, Figure 16 that the model prediction follows the experimental trend. However, the prediction solving the energy conservation equations shifts the species profile towards the burner surface by $3-4 \mathrm{~mm}$. This shift is due to the influence of the probe which causes disturbance of the flame [55]. In Figure 15(a), imposing the experimental temperature profile, experimental and modeling results for major species are in good agreement. However, for $\mathrm{HAB}$ around $7 \mathrm{~mm}$, a peak can be seen in the $\mathrm{CO}$ profile for the experiment, which is 
in contradiction with the model prediction, where we do not observe such steep peaks. The model underpredicts the experimental values by $15 \%$ in peak position. Such a peak is also observed for $\mathrm{NO}$ at same $\mathrm{HAB}(=7 \mathrm{~mm})$ and simulation does not show such a steep peak, both for imposing the temperature profile as well as for solving the energy conservation equation. Further, the mole fractions of the intermediate species $\mathrm{NO}_{2}$ is underpredicted by a factor 3 and $\mathrm{C}_{2} \mathrm{H}_{6}$ are overpredicted by a factor of 2 in the simulation, whereas other intermediate species are over- or underpredicted by a factor of 2. It should be noted that the authors of [39] mentioned that uncertainty of a factor of 2 is expected for intermediates species. The uncertainty of estimated photoionization cross-sections is even larger for radicals due to their quenching effect on the probe surface. Considering this, the model predictions show a reasonable agreement within the experimental uncertainty. In the following, based on the $\mathrm{N}$ - and $\mathrm{C}$-atom mass flow analysis, the main degradation pathways of nitromethane for the flame shown in Figure 15 are discussed. Figure 17 shows the integrated mass flux imposing the experimental temperature profile. Special attention is paid to the species formation and consumption pathways, where nitrogen chemistry is involved because of their complex kinetics. The mass flow analysis in Figure 17(a) indicates that:

- $50 \%$ of $\mathrm{CH}_{3} \mathrm{NO}_{2}$ is dissociated to $\mathrm{CH}_{3}$ and $\mathrm{NO}_{2}$ via the reaction $\mathrm{CH}_{3} \mathrm{NO}_{2}(+\mathrm{M}) \leftrightharpoons \mathrm{CH}_{3}+\mathrm{NO}_{2}(+\mathrm{M})$.

- $27.5 \%$ of $\mathrm{CH}_{3} \mathrm{NO}_{2}$ reacts to $\mathrm{CH}_{2} \mathrm{NO}_{2}$ via $\mathrm{H}$-atom abstraction by $\mathrm{H}$-atoms, $\mathrm{OH}$ and $\mathrm{CH}_{3}$ radicals yielding to $\mathrm{CH}_{2} \mathrm{NO}_{2}$.

- $18 \%$ of $\mathrm{CH}_{3} \mathrm{NO}_{2}$ goes to $\mathrm{CH}_{3} \mathrm{O}$ and $\mathrm{NO}$ via the reaction $\mathrm{CH}_{3} \mathrm{NO}_{2} \leftrightharpoons \mathrm{CH}_{3} \mathrm{O}+\mathrm{NO}$

- $1.3 \%$ of $\mathrm{CH}_{3} \mathrm{NO}_{2}$ reacts with $\mathrm{H}$ atoms forming $\mathrm{CH}_{3} \mathrm{NO}$.

- 3.2\% of $\mathrm{CH}_{3} \mathrm{NO}_{2}$ reacts with $\mathrm{H}$-atoms to $\mathrm{HNO}_{2}$ (not shown in Figure 3(a)) via the route $\mathrm{CH}_{3} \mathrm{NO}_{2}+\mathrm{H} \leftrightharpoons \mathrm{HNO}_{2}+\mathrm{CH}_{3}$.
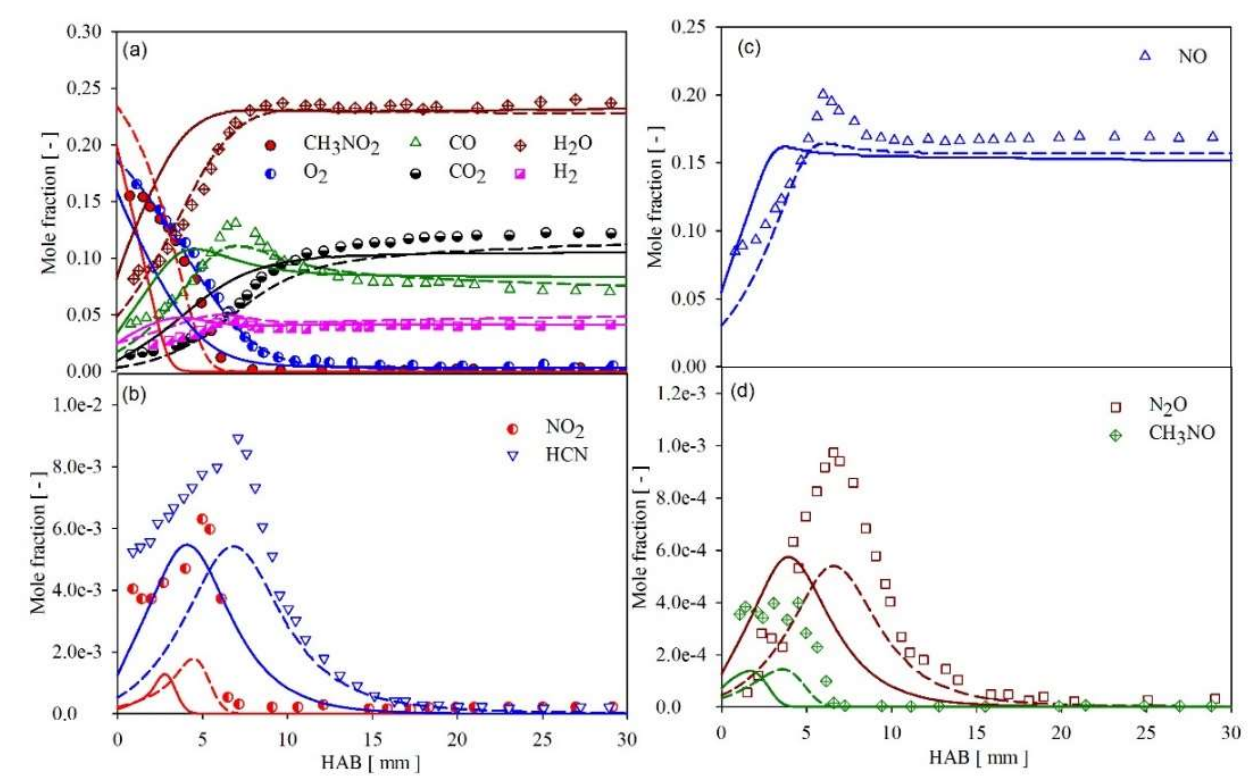

Figure 15: Speciation of premixed $\mathrm{CH}_{3} \mathrm{NO}_{2} / \mathrm{O}_{2} / \mathrm{Ar}$ burner stabilized flame at $4.666 \mathrm{kPa}, \mathrm{T}=298 \mathrm{~K}$, $\phi=1.5$. Symbols: experiments from Zhang et al. [39]; dashed lines: model predictions imposing the experimental temperature profile; solid lines: model predictions solving the energy conservation equation. 


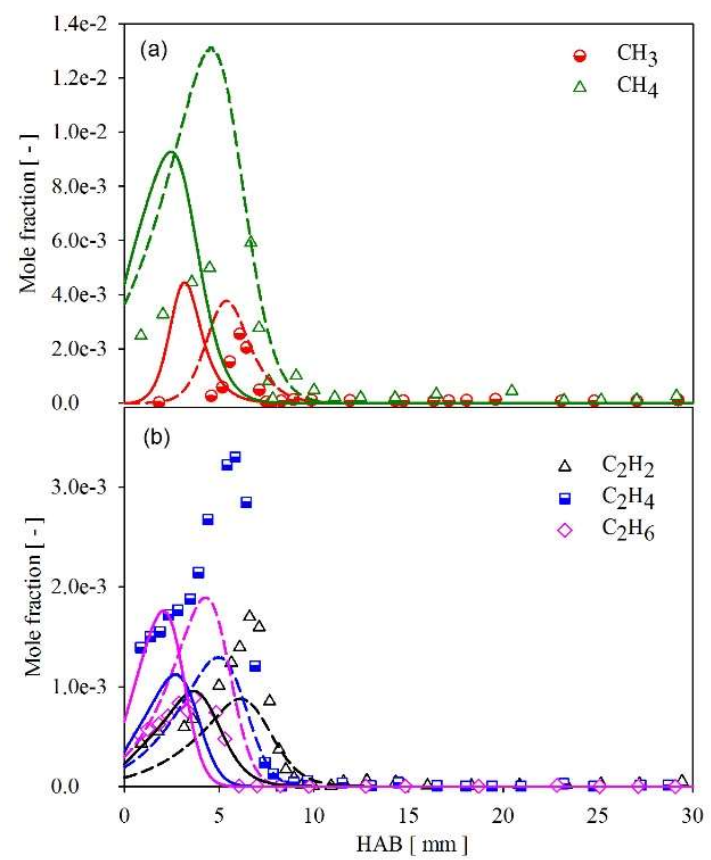

Figure 16: Speciation of premixed $\mathrm{CH}_{3} \mathrm{NO}_{2} / \mathrm{O}_{2} / \mathrm{Ar}$ burner stabilized flame shown in Figure 15.

Symbols: experiments from Zhang et al. [39]; dashed lines: model predictions imposing the experimental temperature profile; solid lines: model predictions solving the energy conservation equation.
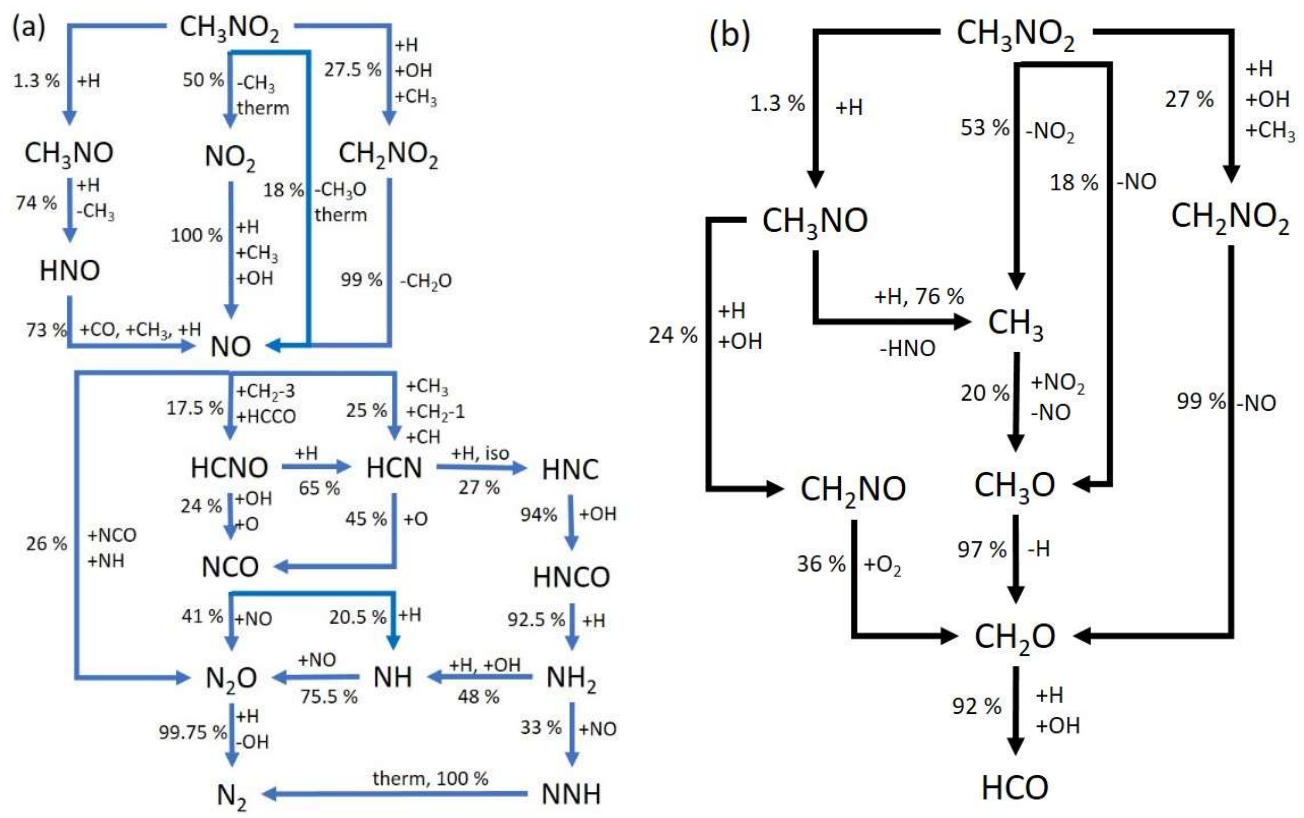

Figure 17: Integrated mass flux analysis for the flame shown in Figure 15. Based on the N-atoms (a), based on C-atoms (b). "therm" and "iso" in the figure mean thermal dissociation and isomerization, respectively.

The formed $\mathrm{NO}_{2}$ completely reacts to $\mathrm{NO}$ via the following reactions: $\mathrm{NO}_{2}+\mathrm{H} \leftrightharpoons \mathrm{NO}+\mathrm{OH}$, $\mathrm{CH}_{3}+\mathrm{NO}_{2} \leftrightharpoons \mathrm{CH}_{3} \mathrm{O}+\mathrm{NO}$, and $\mathrm{NO}+\mathrm{HO}_{2} \leftrightharpoons \mathrm{NO}_{2}+\mathrm{OH} . \mathrm{NO}_{2}+\mathrm{H} \leftrightharpoons \mathrm{NO}+\mathrm{OH}$ is the major contributor to 
$\mathrm{NO}_{2}$ loss. All most all of the $\mathrm{CH}_{2} \mathrm{NO}_{2}$ (99\%) is converted into $\mathrm{NO}$ and $\mathrm{CH}_{2} \mathrm{O}$ via $\mathrm{CH}_{2} \mathrm{NO}_{2} \leftrightharpoons \mathrm{CH}_{2} \mathrm{O}+\mathrm{NO}$.

$\mathrm{CH}_{3} \mathrm{NO}$ indirectly forms $\mathrm{NO}$ via $\mathrm{HNO}$ and methyl radicals in the reaction $\mathrm{CH}_{3} \mathrm{NO}+\mathrm{H} \leftrightharpoons \mathrm{CH}_{3}+\mathrm{HNO}$. Then, $\mathrm{HNO}$ mainly reacts with $\mathrm{CO}(\mathrm{HNO}+\mathrm{CO} \leftrightharpoons \mathrm{HCO}+\mathrm{NO})$, with $\mathrm{CH}_{3}\left(\mathrm{CH}_{3}+\mathrm{HNO} \leftrightharpoons \mathrm{CH}_{4}+\mathrm{NO}\right)$ and with $\mathrm{H}\left(\mathrm{HNO}+\mathrm{H} \leftrightharpoons \mathrm{NO}+\mathrm{H}_{2}\right)$ contributing to the formation of NO. Figure 15(c) shows that the NO mole fraction is as high as that of $\mathrm{H}_{2} \mathrm{O}$ (Figure 15(a)) and is, therefore, one of the major species during $\mathrm{CH}_{3} \mathrm{NO}_{2}$ oxidation.

Next, NO decomposes through different pathways: $26 \%$ of NO is consumed by the reactions $\mathrm{NCO}+\mathrm{NO} \leftrightharpoons \mathrm{N}_{2} \mathrm{O}+\mathrm{CO}$ and $\mathrm{NH}+\mathrm{NO} \leftrightharpoons \mathrm{N}_{2} \mathrm{O}+\mathrm{H} .25 \%$ of $\mathrm{NO}$ is consumed by the following reactions: $\mathrm{CH}_{3}+\mathrm{NO} \leftrightharpoons \mathrm{HCN}+\mathrm{H}_{2} \mathrm{O}, \mathrm{CH}_{2}-1+\mathrm{NO} \leftrightharpoons \mathrm{HCN}+\mathrm{OH}$, and $\mathrm{CH}+\mathrm{NO} \leftrightharpoons \mathrm{HCN}+\mathrm{O}$, other minor reactions contributing to the formation of $\mathrm{HCN}$ are $\mathrm{CH}_{2}-3+\mathrm{NO} \leftrightharpoons \mathrm{HCN}+\mathrm{OH}, \mathrm{C}_{2} \mathrm{H}_{3}+\mathrm{NO} \leftrightharpoons \mathrm{HCN}+\mathrm{CH}_{2} \mathrm{O}$, $\mathrm{C}_{2} \mathrm{H}+\mathrm{NO} \leftrightharpoons \mathrm{HCN}+\mathrm{CO}$ and $\mathrm{HCCO}+\mathrm{NO} \leftrightharpoons \mathrm{HCN}+\mathrm{CO}_{2}$ (not shown here). Further, about $17.5 \%$ of NO reacts with $\mathrm{CH}_{2}-3$ and $\mathrm{HCCO}$ leading to $\mathrm{HCNO}$ mainly via the reactions $\mathrm{CH}_{2}-3+\mathrm{NO} \leftrightharpoons \mathrm{HCNO}+\mathrm{H}$ and $\mathrm{HCCO}+\mathrm{NO} \leftrightharpoons \mathrm{HCNO}+\mathrm{CO}$. Around $65 \%$ of $\mathrm{HCNO}$ reacts with $\mathrm{H}$ to form $\mathrm{HCN}$ via the reaction $\mathrm{HCNO}+\mathrm{H} \leftrightharpoons \mathrm{HCN}+\mathrm{OH}$ and $28 \%$ of $\mathrm{HCNO}$ forms $\mathrm{NCO}$ via these 3 channels: $\mathrm{HCNO}+\mathrm{OH} \leftrightharpoons \mathrm{NCO}+\mathrm{H}+\mathrm{OH}, \mathrm{HCNO}+\mathrm{OH} \leftrightharpoons \mathrm{NCO}+\mathrm{H}_{2} \mathrm{O}$, and $\mathrm{HCNO}+\mathrm{O} \leftrightharpoons \mathrm{NCO}+\mathrm{OH}$. HCN can then react by isomerization to $\mathrm{HNC}(27 \%)$ via $\mathrm{HCN}(+\mathrm{M}) \leftrightharpoons \mathrm{HNC}(+\mathrm{M})$ and $\mathrm{HNC}+\mathrm{H} \leftrightharpoons \mathrm{HCN}+\mathrm{H}$. HCN can also react with $\mathrm{O}$-atoms $(45 \%)$ producing $\mathrm{NCO}(\mathrm{HCN}+\mathrm{O} \leftrightharpoons \mathrm{NCO}+\mathrm{H})$. $\mathrm{HNC}$ formed via the $\mathrm{HCN}$ route almost completely reacts with $\mathrm{OH}$ forming $\mathrm{HNCO}(\mathrm{HNC}+\mathrm{OH} \leftrightharpoons \mathrm{HNCO}+\mathrm{H})$ and $92.5 \%$ of $\mathrm{HNCO}$ reacts with $\mathrm{H}$-atoms yielding $\mathrm{NH}_{2}$ via the route $\mathrm{HNCO}+\mathrm{H} \leftrightharpoons \mathrm{NH}_{2}+\mathrm{CO}$. The last $7.5 \%$ react to $\mathrm{NCO}$ via minor routes (not shown here). $\mathrm{NH}_{2}$ mainly goes to $\mathrm{NH}$ and $\mathrm{NNH}$. Indeed, $48 \%$ of $\mathrm{NH}_{2}$ is consumed to form $\mathrm{NH}$ via the reactions $\mathrm{NH}_{2}+\mathrm{H} \leftrightharpoons \mathrm{NH}+\mathrm{H}_{2}$ and $\mathrm{NH}_{2}+\mathrm{OH} \leftrightharpoons \mathrm{NH}+\mathrm{H}_{2} \mathrm{O}$ and 33\% of $\mathrm{NH}_{2}$ reacts to $\mathrm{NNH}$ via the reaction $\mathrm{NH}_{2}+\mathrm{NO} \leftrightharpoons \mathrm{NNH}+\mathrm{OH}$. Then, $\mathrm{NH}$ reacts with $\mathrm{NO}$ $\left(\mathrm{NH}+\mathrm{NO} \leftrightharpoons \mathrm{N}_{2} \mathrm{O}+\mathrm{H}\right)$ producing $\mathrm{N}_{2} \mathrm{O}$. Almost all of the $\mathrm{N}_{2} \mathrm{O}$ produced during the above process is converted to $\mathrm{N}_{2}$ via the reaction $\mathrm{N}_{2} \mathrm{O}+\mathrm{H} \leftrightharpoons \mathrm{N}_{2}+\mathrm{OH}$ and also all of the $\mathrm{NNH}$ reacts to $\mathrm{N}_{2}$ via thermal dissociation path ( $\mathrm{NNH} \leftrightharpoons \mathrm{N}_{2}+\mathrm{H}$ ).

Overall, the nitrogen atom mass flux analysis in Figure 17(a) can be seen as a two-step process:

- In the first step, almost all of the primary products lead to NO.

- The second step is directed to the decomposition of intermediate species mainly leading to $\mathrm{N}_{2} \mathrm{O}$ which finally goes to $\mathrm{N}_{2}$.

The main pathways for the formation and consumption of species for the three different equivalence ratios $(\phi=1.0,1.5$ and 2.0) remain the same. Mass flux analyses for $\phi=2.0$ and 1.0 are shown in the Supplementary material (Figures S14-S15 and S17-S18). The main difference is observed for the $\mathrm{NH}_{2} \rightarrow \mathrm{NH} / \mathrm{NNH}$ route for the fuel-rich flame ( $\phi=2.0$ ), here $41 \% \mathrm{Of}_{2}$ is consumed to form $\mathrm{NH}$ and $43 \%$ is decomposed to form NNH (see Figure S15 in supplement material) which is in contradiction with the flames at $\phi=1.5$ and 1.0 (see Figures 17(a) and S18). This leads to the conclusion that at higher equivalence ratios, the $\mathrm{NH}_{2} \rightarrow \mathrm{NNH}$ route gets stronger compared to the $\mathrm{NH}_{2} \rightarrow \mathrm{NH}$ route. Additional validation of the burner stabilized premixed flame is provided in the Supplementary material (see Figures S13 and S16). 


\subsubsection{Ignition delay time and laminar flame speed}

Finally, we demonstrate the capability of our model to predict essential features of nitromethane combustion over a wide range of conditions: the ignition timing, and the laminar flame speeds. Figure 18 compares the predicted ignition delay times against shock tube experimental data from the literature. Figure 18(a) shows results of the shock tube experiments by Mathieu et al. [29] at three different equivalence ratios $\left(\phi=0.5,1.0\right.$ and 2.0) at 2 atm for $\mathrm{CH}_{3} \mathrm{NO}_{2} / \mathrm{O}_{2} / \mathrm{Ar}$ mixtures. The model captures the equivalence ratio dependency of ignition delay times very well and agrees with the experimental data for the temperature range studied. Similarly, Figure 18(b) shows ignition delay times measured by Nauclér et al. [27] in a shock tube compared to simulations at different equivalence ratios with changing pressure for $\mathrm{CH}_{3} \mathrm{NO}_{2} / \mathrm{O}_{2} / \mathrm{N}_{2}$ mixtures. We can observe that the model is in excellent agreement with the experimental data. It shows the model capability to predict ignition delay timing with changing mixture composition and pressure.
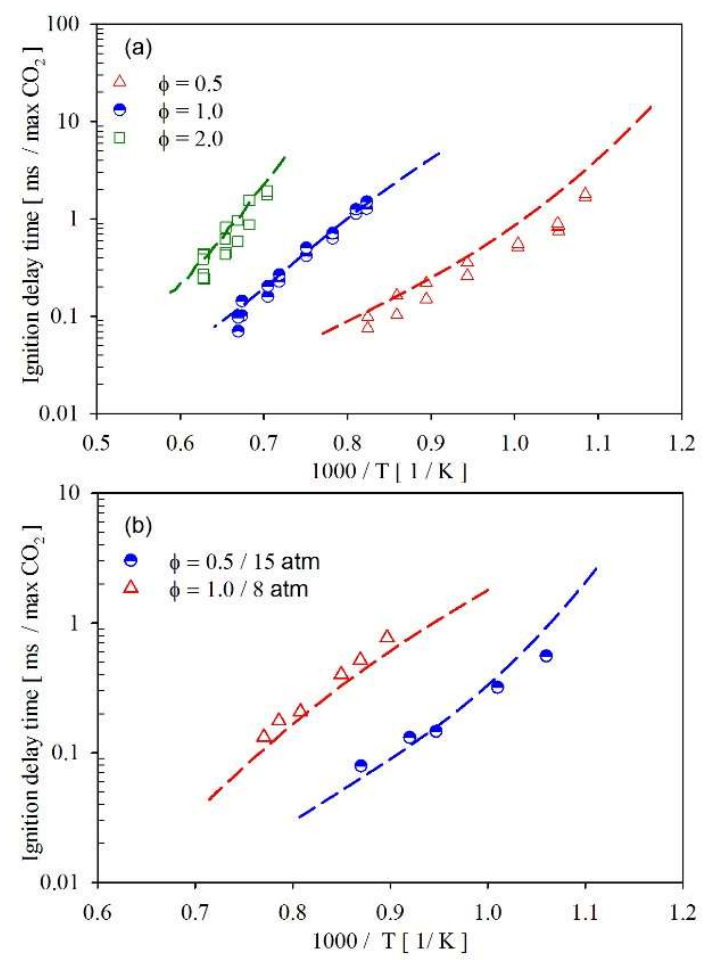

Figure 18: Ignition delay times of $\mathrm{CH}_{3} \mathrm{NO}_{2} / \mathrm{O}_{2} / \mathrm{Ar}\left(\mathrm{a}\right.$ ) and $\mathrm{CH}_{3} \mathrm{NO}_{2} / \mathrm{O}_{2} / \mathrm{N}_{2}$ (b) at different $\phi$ and pressures. $\phi=0.5\left(\mathrm{CH}_{3} \mathrm{NO}_{2} 4 \% / \mathrm{O}_{2} 6 \%\right), \phi=1.0\left(\mathrm{CH}_{3} \mathrm{NO}_{2} 2.857 \% / \mathrm{O}_{2} 2.143 \%\right), \phi=2.0\left(\mathrm{CH}_{3} \mathrm{NO}_{2}\right.$ $1.455 \% / \mathrm{O}_{2}$ 0.545\%) (a); $\phi=0.5\left(\mathrm{CH}_{3} \mathrm{NO}_{2} 4 \% / \mathrm{O}_{2} 10 \%\right), \phi=1.0\left(\mathrm{CH}_{3} \mathrm{NO}_{2} 4 \% / \mathrm{O}_{2} 5 \%\right)$ (b). Balance

$\mathrm{Ar}$ and $\mathrm{N}_{2}$ for above mixtures. Symbols: experiments from [29] (a) and [27] (b); lines:

simulations of this model.

Further ignition delay time sensitivity analysis (towards temperature) is performed and the 20 most sensitive reactions at $\phi=0.5$ and $\mathrm{T}=1100 \mathrm{~K}$ for two pressures, 2 and $15 \mathrm{~atm}$, are shown in Figure 19. A positive sensitivity means that the reaction promotes the reactivity and negative sensitivity means that the reaction inhibits the reactivity. It can be seen for both pressures that 
the most sensitive reactions are $\mathrm{HCO}+\mathrm{NO} \leftrightharpoons \mathrm{HNO}+\mathrm{CO}$ and $\mathrm{O}_{2}+\mathrm{H} \leftrightharpoons \mathrm{OH}+\mathrm{O}$ which is in line with the results from the work of Mathieu et al. [29]. Unlike for the PFR and JSR experiments, the thermal dissociation reaction of $\mathrm{CH}_{3} \mathrm{NO}_{2}$ is not among the most sensitive reactions. However, the reaction still appears in sensitivity analyses and its sensitivity decreases at 15 atm compared to $2 \mathrm{~atm}$. The recombination reactions of $\mathrm{NO}$ with $\mathrm{H}$ and $\mathrm{O}$-atoms forming $\mathrm{HNO}$ and $\mathrm{NO}_{2}$ respectively have much higher sensitivity at $15 \mathrm{~atm}$ than at $2 \mathrm{~atm}$. It can be seen in Figure 19 that the sensitivity of most of the reactions increases at higher pressure, while only a few reactions $\left(\mathrm{HCO}+\mathrm{O}_{2} \leftrightharpoons \mathrm{CO}+\mathrm{HO}_{2}, \mathrm{HCO}+\mathrm{NO} \leftrightharpoons \mathrm{HNO}+\mathrm{CO}\right.$, and $\left.\mathrm{CH}_{2} \mathrm{O}+\mathrm{OH} \leftrightharpoons \mathrm{HCO}+\mathrm{H}_{2} \mathrm{O}\right)$ show a decreased sensitivity. It is also interesting to see (in Figure 19) that one of the reaction $\left(\mathrm{CH}_{4}+\mathrm{OH} \leftrightharpoons \mathrm{CH}_{3}+\mathrm{H}_{2} \mathrm{O}\right)$ alter the sensitivity direction at higher pressure. Overall, it can be seen that most of the sensitive reactions appear within the nitrogen chemistry. Additional model validation for the ignition delay times of nitromethane as well as speciation in shock tube is shown in the Supplementary material (Figures S19-S21).

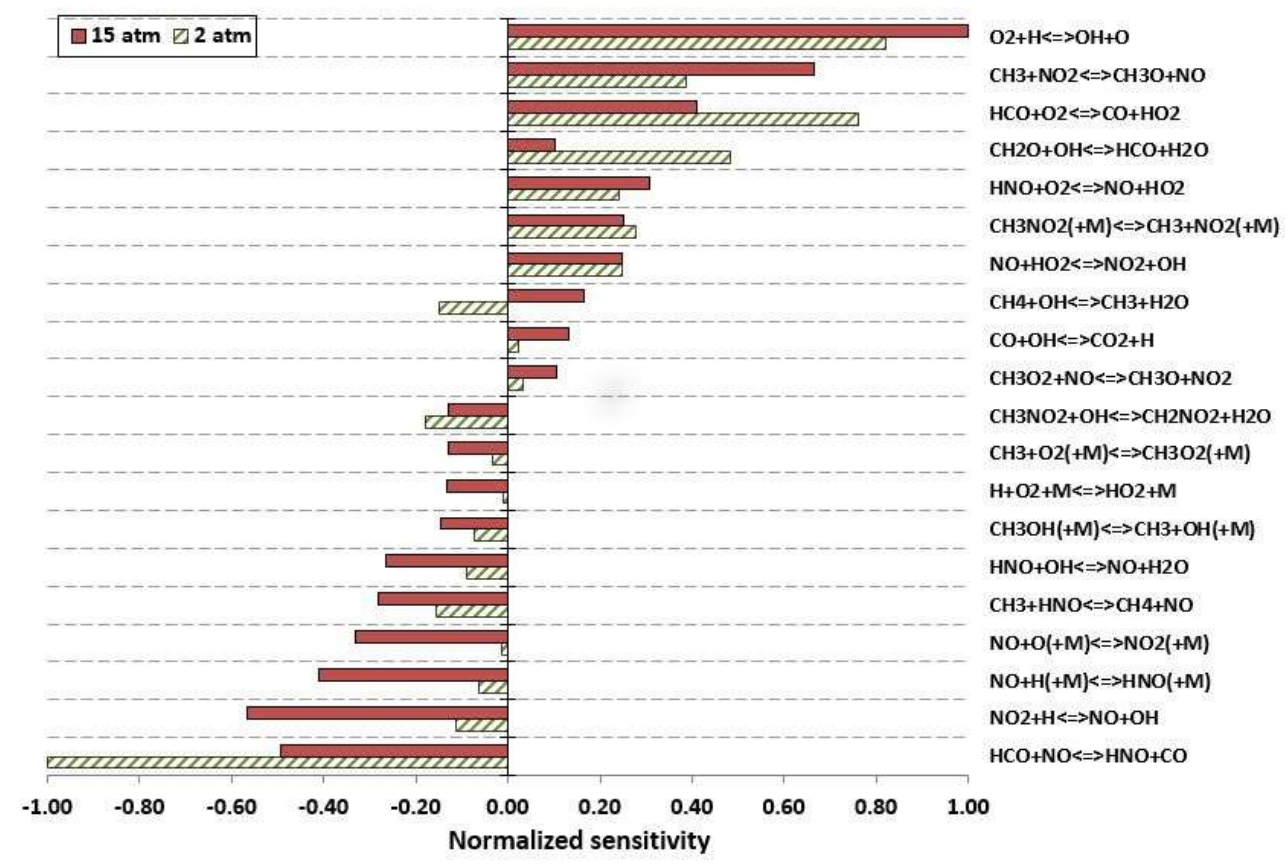

Figure 19: Ignition delay time sensitivity analysis at $\phi=0.5$ and $\mathrm{T}=1100 \mathrm{~K}$. For $2 \mathrm{~atm}$ (mixture condition from [29]), for 15 atm (mixture condition from [27]) see Figure 18.

In Figure 20, laminar flame speeds of a $\mathrm{CH}_{3} \mathrm{NO}_{2}$ /air flame at $423 \mathrm{~K}$ are compared against the model predictions for initial pressures of 1, 2, and 3 bar. The measurements (symbols) were performed by Brequigny et al. [28] for propagating spherical flames. To determine the equivalence ratio, they used the equation $\mathrm{CH}_{3} \mathrm{NO}_{2}+0.75\left(\mathrm{O}_{2}+3.76 \mathrm{~N}_{2}\right) \leftrightharpoons \mathrm{CO}_{2}+1.5 \mathrm{H}_{2} \mathrm{O}+3.32 \mathrm{~N}_{2}$ (Equation (1)). The maximum flame speed was observed (experimentally) for lean mixtures around $\phi=0.7-0.8$ (see Figure S22 in supplement material). From the studies listed in Table 1, [28] is the only one to use Equation (1) for determining equivalence ratios. All other studies listed in Table 1 used (and/or suggested) $\mathrm{CH}_{3} \mathrm{NO}_{2}+1.25 \quad \mathrm{O}_{2} \leftrightharpoons \mathrm{CO}_{2}+1.5 \quad \mathrm{H}_{2} \mathrm{O}+\mathrm{NO}$ (Eq. (2)) as the correct equation for determining equivalence ratios where $\mathrm{NO}$ is a major product instead of $\mathrm{N}_{2}$. It is seen in the present work as well as in other studies discussed above, at different conditions and for different reactors, 
that NO is a more stable product and found in higher concentrations. Nevertheless, the equivalence ratios according to Equations (1) and (2) have a linear relationship of $\phi$ Equation (1) $=0.6 \times \phi$ Equation (2) and thereby they can be directly converted into each other which is also suggested by Faghih and Chen [56]. For the laminar flame speed shown in Figure 20, we recalculated the equivalence ratio of Brequigny et al. [28] using Equation (2). We can see (Figure 20 ) that the maximum laminar flame speed is shifted towards the rich side (to around $\phi=1.25$ ) which is generally observed in hydrocarbon laminar flame speeds. The model derived in this work is able to capture the experimental trends with regard to the variation of equivalence ratio and pressure. However, the model overpredicts the laminar flame speed for very rich conditions ( $\phi>1.8)$. Further, the laminar flame speeds at $1 \mathrm{~atm}$ and at elevated temperature (338-358 K) were measured by Nauclér et al. [37] (see Figure S23 in supplementary material). Here, in contrast to the observation in Figure 20, the model underpredicts the laminar flame speed by $4 \mathrm{~cm} / \mathrm{s}$ at $\phi=1.2$ but this discrepancy is smaller for the lean and rich sides. Nevertheless, we can state that the model is able to predict the temperature dependency of the laminar flame speed for the range of equivalence ratios studied here (see Figure S23 in supplementary material). At present, we cannot say whether the remaining discrepancy is from the experiments or from the kinetic model. In general, the model is in good agreement with the measurements from Brequigny et al. [28] but underpredicts the measurements of Nauclér et al. [37].

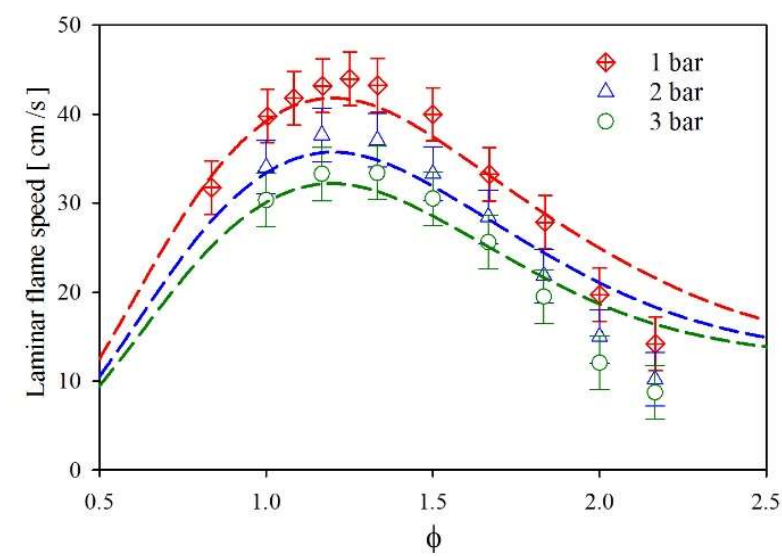

Figure 20: Laminar flame speed of $\mathrm{CH}_{3} \mathrm{NO}_{2}$ /air at $423 \mathrm{~K}$ and three different pressures 1, 2 and 3 bar. Symbols: measurements from [28]; lines: this model.

\section{Effect of reaction rate uncertainty on model predictions}

In the present work, we observed that the model is unable to predict several intermediate species profiles under pyrolysis conditions for both flow reactor and JSR experiments despite predicting the fuel decomposition very well (Figure 3, Figure 4, Figure 7, Figure 8). We have performed an uncertainty analysis to investigate if a better choice of the kinetic parameters of the elementary reactions in the $\mathrm{C} / \mathrm{H} / \mathrm{O} / \mathrm{N}$ chemistry can improve the model performance. Before discussing the results of this uncertainty analysis, we present a brief overview of the model and discuss the present choice of rate parameters. In our previous work [32], we developed the $\mathrm{H} / \mathrm{O} / \mathrm{N}$ chemistry and the kinetic model was extensively validated against a large set of published experimental data 
set and the choice of rate parameters for each reaction involved in this $(\mathrm{H} / \mathrm{O} / \mathrm{N})$ system has been explained there. Furthermore, the $\mathrm{H} / \mathrm{O} / \mathrm{N}$ chemistry was extended in our recent study [31] to include $\mathrm{C}_{1}-\mathrm{C}_{2}$ kinetics and cross-reactions between $\mathrm{C}$ and $\mathrm{N}$ chemistry. It was demonstrated in [31] that the model performed very well for a broad range of experimental conditions (speciation in a flow reactor, JSR and BSF as well as for laminar flame speed and ignition delay times) and was able of describing the $\mathrm{C}_{1}-\mathrm{C}_{2} / \mathrm{NO}_{\mathrm{x}}$ interaction reasonably well, even for very rich mixtures. For detailed information, the reader can refer to two recent studies [31,32]. The model development approach in all of our previous work is hierarchically in nature as it is in this work. It is well known that the nitrogen chemistry is more complex than that of simple hydrocarbons, in which reaction rate determination often based on analogy works quite well. Since experimental or high-level theoretical studies are unfortunately scarce, most of the reaction rates used for the elementary reactions in the $\mathrm{CH}_{3} \mathrm{NO}_{2}$ sub-set are derived from analogy or from the QRRK estimation, and are definitely prone to high uncertainty. The available literature is focused on the unimolecular dissociation of $\mathrm{CH}_{3} \mathrm{NO}_{2}$ as discussed above in Section 3.1. To investigate the discrepancy between model predictions and experimental data, we choose the pyrolysis case shown in Figure 3, Figure 4. A sensitivity analysis was performed towards $\mathrm{HCN}$ and $\mathrm{C}_{2} \mathrm{H}_{6}$ and the sensitive reactions from the $\mathrm{C} / \mathrm{H} / \mathrm{O} / \mathrm{N}$ chemistry with regard to these targets are listed in Table 4 and the order of sensitivity is shown in Figure 21. HCN and $\mathrm{C}_{2} \mathrm{H}_{6}$ have been chosen because these species were significantly under- and overpredicted. Table 4 also provides the rate parameters for the chosen sensitive reactions and their rate constant uncertainty where available in literature. Where not available, we use $50 \%$ which is reasonable compared to other values listed in Table 4 . First, the reaction rate parameters of sensitive reactions (listed in Table 4) are modified (within the uncertainty) to improve HCN, shown by the solid lines in Figure 22, Figure 23. It can be observed that the HCN concentration increases as expected (moving closer to the experimental data), but the maximum concentration is still significantly underpredicted. However, these changes have a negative impact on the $\mathrm{C}_{2} \mathrm{H}_{6}$ concentration profile (moving away from the experimental data) but has positive impact on $\mathrm{CH}_{3} \mathrm{OH}$ (moving closer to the experimental data). Similar observations can be seen for other species. In the second case, the reaction rate parameters of sensitive reactions (listed in Table 4) are modified (within the uncertainty) in order to improve $\mathrm{C}_{2} \mathrm{H}_{6}$ shown by the dotted lines in Figure 22, Figure 23. As expected, the $\mathrm{C}_{2} \mathrm{H}_{6}$ concentration profile decreases (moving closer to the experimental data) but similar to the previous case, there are other species, for which the agreement worsens. From this analysis, we conclude that with the present understanding on nitromethane degradation kinetics we are not able to reasonably predict all the intermediate species for pyrolysis conditions and this problem should be addressed by the combustion community in future work. Further studies on elementary reactions along the nitromethane degradation pathways are highly desirable. 
Table 4: Selected sensitive reactions for the pyrolysis experiment shown in Figure 22, Figure 23. Est.: estimated value, Exp.: experimentally determined, Theory: theoretically calculated, N/A: not available. Units: $\mathrm{cm}^{3}$-mol-s-cal.

\begin{tabular}{|c|c|c|c|c|c|c|}
\hline \multirow[b]{2}{*}{ Reactions } & \multirow[b]{2}{*}{ A } & \multirow[b]{2}{*}{$\mathrm{n}$} & \multirow[b]{2}{*}{ Ea } & \multicolumn{3}{|c|}{ Uncertainty } \\
\hline & & & & Method & $\%( \pm)$ & Ref. \\
\hline $\mathrm{CH}_{2} \mathrm{NO}_{2}+\mathrm{CH}_{3} \leftrightharpoons \mathrm{C}_{2} \mathrm{H}_{5}+\mathrm{NO}_{2}$ & $5.00 \mathrm{E}+13$ & 0 & $0.00 \mathrm{E}+00$ & Est. & $\mathrm{N} / \mathrm{A}$ & [39] \\
\hline $\mathrm{CH}_{2} \mathrm{NO}_{2} \leftrightharpoons \mathrm{CH}_{2} \mathrm{O}+\mathrm{NO}$ & $1.00 \mathrm{E}+13$ & 0 & $3.60 \mathrm{E}+04$ & Exp. & $\mathrm{N} / \mathrm{A}$ & [57] \\
\hline $\mathrm{CH}_{3} \mathrm{NO}_{2}(+\mathrm{M}) \leftrightharpoons \mathrm{CH}_{3}+\mathrm{NO}_{2}(+\mathrm{M})$ & $1.80 \mathrm{E}+16$ & 0 & $5.85 \mathrm{E}+04$ & Exp. & 33 & {$[22,26]$} \\
\hline Low pressure rate & $1.26 \mathrm{E}+17$ & 0 & $4.20 \mathrm{E}+04$ & Exp. & 25 & \\
\hline $\mathrm{CH}_{3} \mathrm{O}+\mathrm{NO} \leftrightharpoons \mathrm{CH}_{2} \mathrm{O}+\mathrm{HNO}$ & $1.30 \mathrm{E}+14$ & -0.7 & $0.00 \mathrm{E}+00$ & Eva. & N/A & [58] \\
\hline 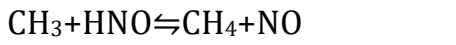 & $1.50 \mathrm{E}+11$ & 0.76 & $3.48 \mathrm{E}+02$ & Theory & N/A & [59] \\
\hline $\mathrm{CH}_{3}+\mathrm{NO} \leftrightharpoons \mathrm{H}_{2} \mathrm{CN}+\mathrm{OH}$ & $1.50 \mathrm{E}-01$ & 3.52 & $3.95 E+03$ & Theory & $\mathrm{N} / \mathrm{A}$ & [60] \\
\hline $\mathrm{CH}_{3}+\mathrm{NO} \leftrightharpoons \mathrm{HCN}+\mathrm{H}_{2} \mathrm{O}$ & $1.50 \mathrm{E}-01$ & 3.52 & $3.95 \mathrm{E}+03$ & Theory & N/A & [60] \\
\hline $\mathrm{CH}_{3} \mathrm{NO}_{2}+\mathrm{H} \leftrightharpoons \mathrm{CH}_{2} \mathrm{NO}_{2}+\mathrm{H}_{2}$ & $5.40 \mathrm{E}+02$ & 3.5 & $5.20 \mathrm{E}+03$ & Est. & N/A & [26] \\
\hline $\mathrm{CH}_{3} \mathrm{NO}_{2}+\mathrm{H} \leftrightharpoons \mathrm{CH}_{3}+\mathrm{HNO}_{2}$ & $3.30 \mathrm{E}+12$ & 0 & $3.73 \mathrm{E}+03$ & Exp. & 25 & [61] \\
\hline $\mathrm{C}_{2} \mathrm{H}_{3}+\mathrm{NO} \leftrightharpoons \mathrm{HCN}+\mathrm{CH}_{2} \mathrm{O}$ & $7.00 \mathrm{E}+21$ & -3.4 & $1.03 \mathrm{E}+03$ & Theory & N/A & [62] \\
\hline $\mathrm{C}_{2} \mathrm{H}_{3}+\mathrm{NO}_{2} \leftrightharpoons \mathrm{CH}_{2} \mathrm{CHO}+\mathrm{NO}$ & $7.70 \mathrm{E}+14$ & -0.6 & $0.00 \mathrm{E}+00$ & Exp. & 25 & [63] \\
\hline $\mathrm{CH}_{3} \mathrm{NO}_{2}+\mathrm{H} \leftrightharpoons \mathrm{CH}_{3} \mathrm{NO}+\mathrm{OH}$ & $1.40 \mathrm{E}+12$ & 0 & $3.73 E+03$ & Exp. & 25 & [61] \\
\hline $\mathrm{CH}_{3} \mathrm{NO}_{2}+\mathrm{OH} \leftrightharpoons \mathrm{CH}_{2} \mathrm{NO}_{2}+\mathrm{H}_{2} \mathrm{O}$ & $5.00 \mathrm{E}+05$ & 2 & $1.00 \mathrm{E}+03$ & Est. & N/A & [26] \\
\hline $\mathrm{CH}_{3}+\mathrm{NO}_{2} \leftrightharpoons \mathrm{CH}_{3} \mathrm{O}+\mathrm{NO}$ & $4.00 \mathrm{E}+13$ & -0.2 & $0.00 \mathrm{E}+00$ & Theory & 30 & [26] \\
\hline $\mathrm{CH}_{3} \mathrm{NO}_{2}+\mathrm{OH} \leftrightharpoons \mathrm{CH}_{3} \mathrm{OH}+\mathrm{NO}_{2}$ & $2.00 \mathrm{E}+10$ & 0 & $1.00 \mathrm{E}+03$ & Est. & N/A & [26] \\
\hline $\mathrm{CH}_{3} \mathrm{NO}_{2}+\mathrm{C}_{2} \mathrm{H}_{5} \leftrightharpoons \mathrm{CH}_{2} \mathrm{NO}_{2}+\mathrm{C}_{2} \mathrm{H}_{6}$ & $3.00 \mathrm{E}+11$ & 0 & $1.17 \mathrm{E}+04$ & Est. & $\mathrm{N} / \mathrm{A}$ & [29] \\
\hline $\mathrm{CH}_{3} \mathrm{NO}_{2}+\mathrm{CH}_{3} \leftrightharpoons \mathrm{CH}_{2} \mathrm{NO}_{2}+\mathrm{CH}_{4}$ & $5.50 \mathrm{E}-01$ & 4 & $8.30 \mathrm{E}+03$ & Est. & $\mathrm{N} / \mathrm{A}$ & [26] \\
\hline
\end{tabular}

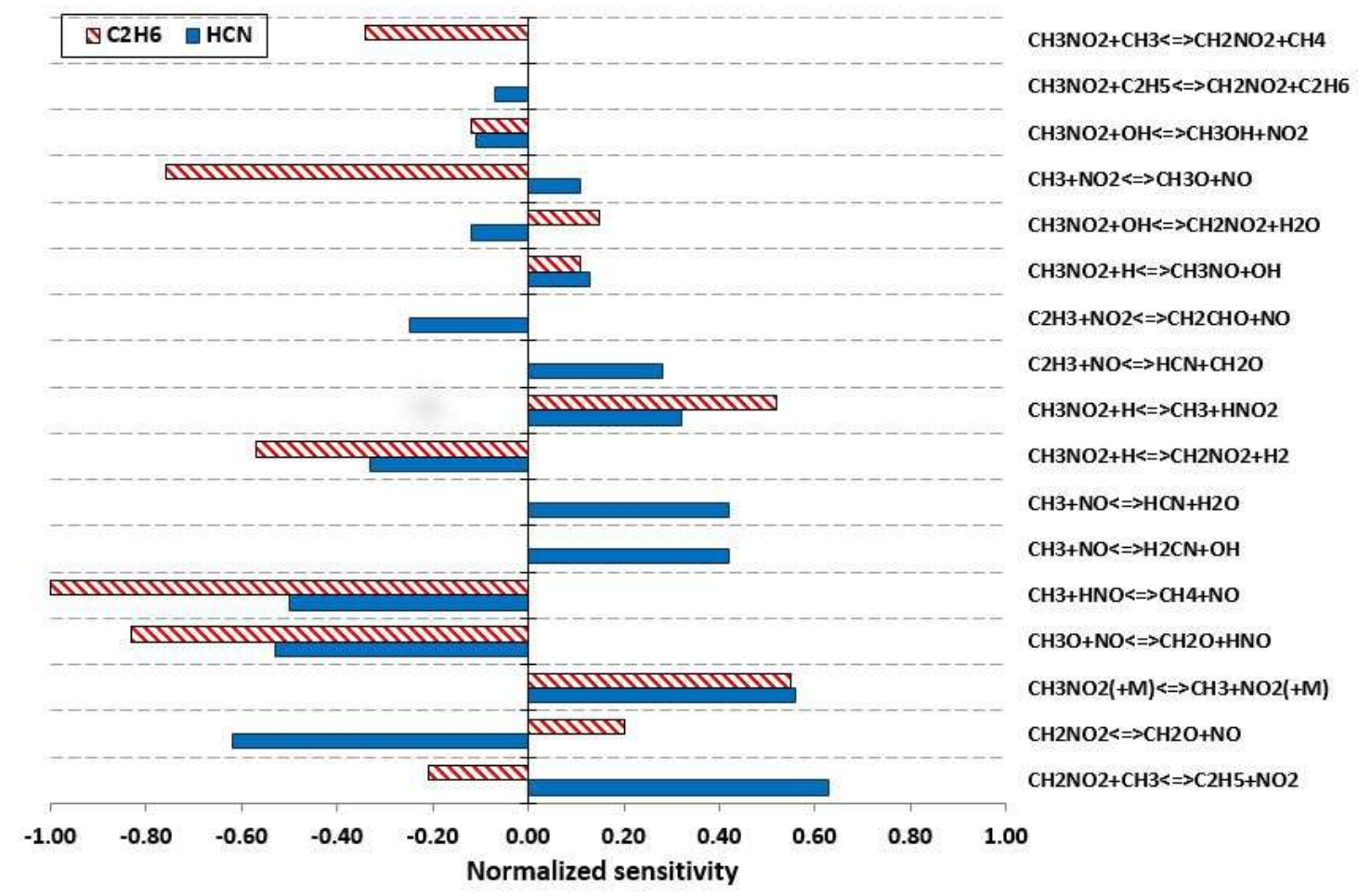

Figure 21: Sensitivity analysis for pyrolysis condition shown in Figure 22 at $780 \mathrm{~K}$, towards HCN (blue) and towards $\mathrm{C}_{2} \mathrm{H}_{6}$ (red). (For interpretation of the references to colour in this figure legend, the reader is referred to the web version of this article.) 

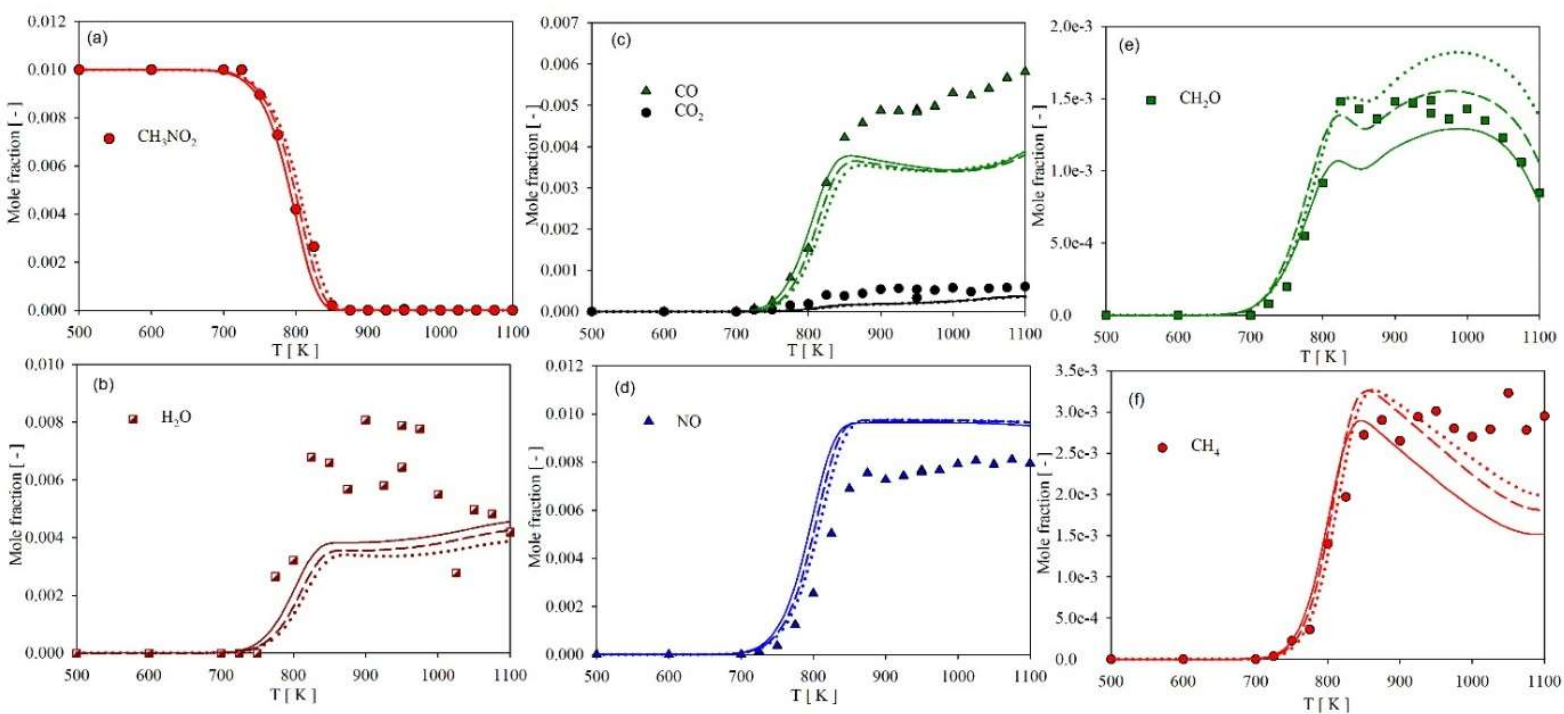

Figure 22: Pyrolysis of $\mathrm{CH}_{3} \mathrm{NO}_{2}$ 1\%/He 99\% (on a mole basis) in a flow reactor at 1.07 bar, a residence time of $2.0 \mathrm{~s}$ in the isothermal zone of the reactor. Symbols: present work; dashed lines: prediction with the proposed model, solid lines: model predictions with modified rate constant for reactions listed in Table 4 (targeting HCN), dotted lines: model predictions with modified rate constant for reactions listed in Table 4 (targeting $\mathrm{C}_{2} \mathrm{H}_{6}$ ).
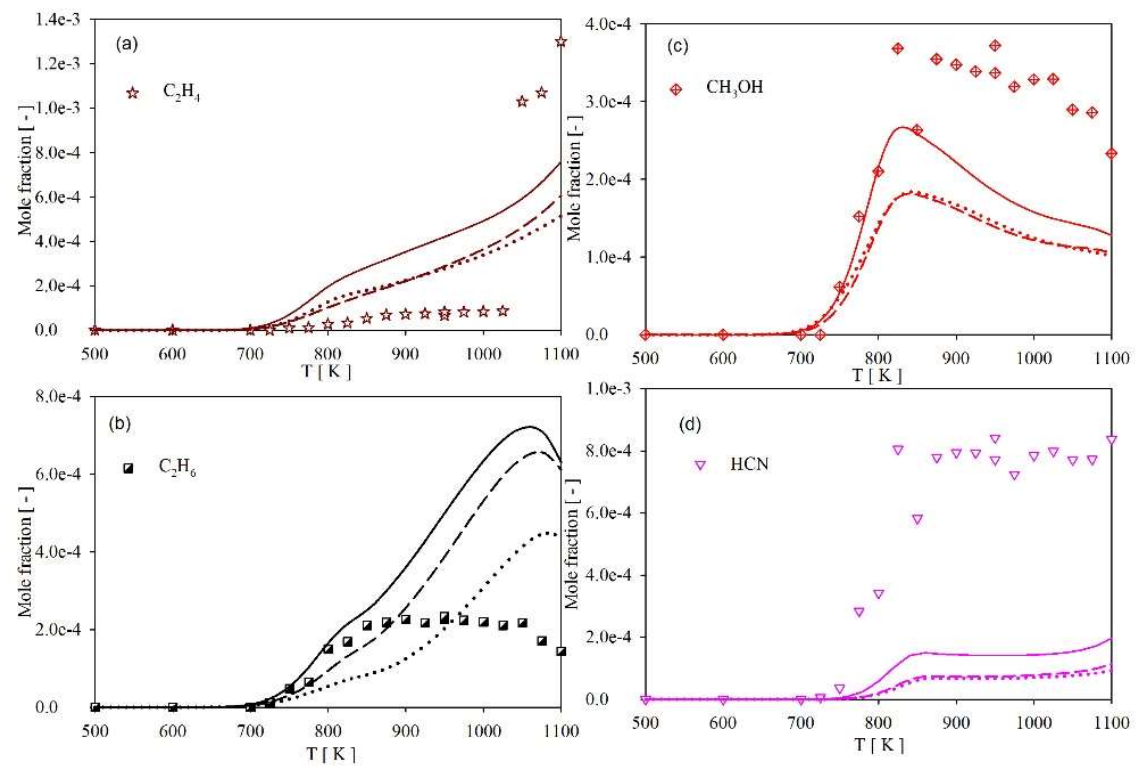

Figure 23: Pyrolysis of $\mathrm{CH}_{3} \mathrm{NO}_{2}$ 1\%/He 99\% (on a mole basis) in a flow reactor at 1.07 bar, a residence time of $2.0 \mathrm{~s}$ in the isothermal zone of the reactor. Symbols: present work; dashed lines: prediction with the proposed model, solid lines: model predictions with modified rate constant for reactions listed in Table 4 (targeting HCN), dotted lines: model predictions with modified rate constant for reactions listed in Table 4 (targeting $\mathrm{C}_{2} \mathrm{H}_{6}$ ).

\section{Conclusions}

The pyrolysis of nitromethane was studied at 1.07 bar in a flow reactor and in a jet-stirred reactor. Mole fraction profiles of products were determined using gas chromatography and FTIR 
spectroscopy. Based on the present measurements and published experimental data, a detailed reaction mechanism for the pyrolysis and oxidation of nitromethane has been developed. A number of published experiments have been selected to demonstrate that important features of the $\mathrm{CH}_{3} \mathrm{NO}_{2}$ chemistry are well captured by the broadly validated reaction mechanism presented in this work. Overall, there is a good agreement between model predictions and measurements for the wide range of experimental conditions investigated. Among the nitrogenous species, NO is found to be a major product for both pyrolysis and oxidation. The kinetic analysis suggests that the thermal dissociation channel is the main path for the initial nitromethane decomposition followed by the H-atom abstraction channel. The most sensitive reactions for nitromethane pyrolysis in a flow reactor and during pyrolysis and oxidation in a jet-stirred reactor are found to be $\mathrm{CH}_{3} \mathrm{NO}_{2}(+\mathrm{M}) \leftrightharpoons \mathrm{CH}_{3}+\mathrm{NO}_{2}(+\mathrm{M})$ and $\mathrm{CH}_{3}+\mathrm{NO}_{2} \leftrightharpoons \mathrm{CH}_{3} \mathrm{O}+\mathrm{NO}$. The simple decomposition pathway (with regard to the $\mathrm{C}$-atom flow) of nitromethane during pyrolysis can be represented as $\mathrm{CH}_{3} \mathrm{NO}_{2} \rightarrow \mathrm{CH}_{3} \rightarrow \mathrm{CH}_{3} \mathrm{O} \rightarrow \mathrm{CH}_{2} \mathrm{O} \rightarrow \mathrm{HCO}$. For the burner stabilized premixed flame the thermal dissociation channel $\mathrm{CH}_{3} \mathrm{NO}_{2}(+\mathrm{M}) \leftrightharpoons \mathrm{CH}_{3}+\mathrm{NO}_{2}(+\mathrm{M})$ gains importance as mixtures become richer while the $\mathrm{H}$-atom abstraction channel is weakened. Under flame conditions, $\mathrm{NO}$ is mainly formed via the $\mathrm{NO}_{2}$ route: $\mathrm{NO}_{2}+\mathrm{H} \leftrightharpoons \mathrm{NO}+\mathrm{OH}, \mathrm{NO}_{2}+\mathrm{CH}_{3} \leftrightharpoons \mathrm{CH}_{3} \mathrm{O}+\mathrm{NO}$. Based on the mass flux analysis, several important reactions were identified involving hydrocarbon radicals and nitric oxides. Published rate parameters of reactions related to nitromethane chemistry are limited and the ones available in the literature are decades old. Further work is required in this area to enhance the model development and improve the understanding of nitromethane combustion and pyrolysis. The here derived model is capable to serve as the base mechanism for hydrocarbon fuels and for oxygenated fuels higher than $\mathrm{C}_{2}$ and nitrogen-containing compounds higher than $\mathrm{C}_{1}$ as well as for compounds with nitrogen only.

\section{Acknowledgments}

The experimental work on $\mathrm{CH}_{3} \mathrm{NO}_{2}$ pyrolysis has been supported by TERBIS, 943 rue Pasteur, 60700 Pont Sainte Maxence, France. This collaboration was enabled by the COST Action CM1404 "Chemistry of smart energy carriers and technologies - SMARTCATs".

\section{Supplementary material}

Additional comparisons and kinetic analyses

\section{References}

[1] Boyer E, Kuo KK. High-pressure combustion behavior of nitromethane. 35th Jt. Propuls. Conf. Exhib., Los Angeles,CA,U.S.A.: American Institute of Aeronautics and Astronautics; 1999. doi:10.2514/6.1999-2358.

[2] Boyer E, Kuo KK. Modeling of nitromethane flame structure and burning behavior. Proc Combust Inst 2007;31:2045-53. doi:10.1016/j.proci.2006.07.025.

[3] Kelzenberg S, Eisenreich N, Eckl W, Weiser V. Modelling Nitromethane Combustion. Propellants, Explos Pyrotech 1999;24:189-94. doi:10.1002/(SICI)1521-4087(199906)24:03<189::AIDPREP189>3.0.C0;2-P. 
[4] Starkman ES. Nitroparaffins as Potential Engine Fuel. Ind Eng Chem 1959;51:1477-80. doi:10.1021/ie50600a035.

[5] Boyer EJ. Combustion Characteristics and Flame Structure of Nitromethane Liquid Monopropellant, PhD Thesis. The Pennsylvania State University, 2005.

[6] Shekhar H. Explosive Characteristics and Shaped Charge Applications of Nitromethane (NM): A Review. Cent Eur J Energ Mater 2012;9:87-97.

[7] Raine RR, Thorwarth H. Performance and Combustion Characteristics of a Glow-Ignition TwoStroke Engine. SAE Tech Pap 2004. doi:10.4271/2004-01-1407.

[8] Bush KC, Germane GJ, Hess GL. Improved Utilization of Nitromethane as an Internal Combustion Engine Fuel. SAE Tech Pap 1985;852130. doi:10.4271/852130.

[9] Ferguson CR, Kirkpatrick A. Internal combustion engines : Applied Thermosciences, 3rd Edition. 2015.

[10] Yokoo N, Miyamoto Y, Nakata K, Obata K, Aoki G, Watanabe M. Research of Fuel Components to Enhance Engine Thermal Efficiency. Soc Automot Eng Japan, Inc 2018;49:241-6. doi:10.11351/jsaeronbun.49.241.

[11] Cracknell RF, Head RA, McAllister LJ, Andrae JCG. Octane Sensitivity in Gasoline Fuels Containing Nitro-Alkanes: A Possible Means of Controlling Combustion Phasing for HCCI. SAE Tech. Pap. 2009-01-0301, 2009. doi:10.4271/2009-01-0301.

[12] Inomata S, Fujitani Y, Fushimi A, Tanimoto H, Sekimoto K, Yamada H. Field measurement of nitromethane from automotive emissions at a busy intersection using proton-transfer-reaction mass spectrometry. Atmos Environ 2014;96:301-9. doi:10.1016/J.ATMOSENV.2014.07.058.

[13] Inomata S, Tanimoto H, Fujitani Y, Sekimoto K, Sato K, Fushimi A, et al. On-line measurements of gaseous nitro-organic compounds in diesel vehicle exhaust by proton-transfer-reaction mass spectrometry. Atmos Environ 2013;73:195-203. doi:10.1016/J.ATMOSENV.2013.03.035.

[14] Sekimoto K, Inomata S, Tanimoto H, Fushimi A, Fujitani Y, Sato K, et al. Characterization of nitromethane emission from automotive exhaust. Atmos Environ 2013;81:523-31. doi:10.1016/J.ATMOSENV.2013.09.031.

[15] Kruchoski MP. New Lower Estimate for Soils Contaminated with Secondary Explosives and the Associated Implications. Fort Belvoir, USA: 1997. doi:ADA360739.

[16] Bart JC, Judd LL, Hoffman KE, Wilkins AM, Kusterbeck AW. Application of a portable immunosensor to detect the explosives TNT and RDX in groundwater samples. Environ Sci Technol 1997;31:1505-11. doi:10.1021/es960777l.

[17] van Ham NHA. Recycling and disposal of munitions and explosives. Waste Manag 1998;17:147-50. doi:10.1016/S0956-053X(97)10014-9.

[18] Garg R, Grasso D, Hoag G. Treatment of Explosives Contaminated Lagoon Sludge. Hazard Waste Hazard Mater 1991;8:319-40. doi:10.1089/hwm.1991.8.319.

[19] Sturtzer M-O, Lamoureux N, Matignon C, Desbordes D, Presles H-N. On the origin of the double cellular structure of the detonation in gaseous nitromethane and its mixtures with oxygen. Shock Waves 2005;14:45-51. doi:10.1007/s00193-004-0236-3.

[20] Presles HN, Desbordes D, Guirard M, Guerraud C. Gaseous nitromethane and nitromethane-oxygen mixtures: A new detonation structure. Shock Waves 1996;6:111-4. doi:10.1007/BF02515194.

[21] Menikoff R, Sam Shaw M. Modeling detonation waves in nitromethane. Combust Flame 2011;158:2549-58. doi:10.1016/j.combustflame.2011.05.009.

[22] Glänzer K, Troe J. Thermische Zerfallsreaktionen von Nitroverbindungen I: Dissoziation von Nitromethan. Helv Chim Acta 1972;55:2884-93. doi:10.1002/hlca.19720550821. 
[23] Annesley CJ, Randazzo JB, Klippenstein SJ, Harding LB, Jasper AW, Georgievskii Y, et al. Thermal Dissociation and Roaming Isomerization of Nitromethane: Experiment and Theory. J Phys Chem A 2015;119:7872-93. doi:10.1021/acs.jpca.5b01563.

[24] Hsu DSY, Lin MC. Laser probing and kinetic modeling of NO and CO production in shock-wave decomposition of nitromethane under highly diluted conditions. J Energ Mater 1985;3:95-127. doi:10.1080/07370658508012337.

[25] Matsugi A, Shiina H. Thermal Decomposition of Nitromethane and Reaction between CH3 and NO2. J Phys Chem A 2017;121:4218-24. doi:10.1021/acs.jpca.7b03715.

[26] Glarborg P, Bendtsen AB, Miller JA. Nitromethane Dissociation: Implications For the CH3 + NO2 Reaction. Int J Chem Kinet 1999;31:591-602.

[27] Nauclér JD, Li Y, Nilsson EJK, Curran HJ, Konnov AA. An experimental and modeling study of nitromethane + 02 + N2 ignition in a shock tube. Fuel 2016;186:629-38. doi:10.1016/j.fuel.2016.09.003.

[28] Brequigny P, Dayma G, Halter F, Mounaïm-Rousselle C, Dubois T, Dagaut P. Laminar burning velocities of premixed nitromethane/air flames: An experimental and kinetic modeling study. Proc Combust Inst 2015;35:703-10. doi:10.1016/j.proci.2014.06.126.

[29] Mathieu O, Giri B, Agard AR, Adams TN, Mertens JD, Petersen EL. Nitromethane ignition behind reflected shock waves: Experimental and numerical study. Fuel 2016;182:597-612. doi:10.1016/j.fuel.2016.05.060.

[30] Brackmann C, Nauclér JD, El-Busaidy S, Hosseinia A, Bengtsson PE, Konnov AA, et al. Experimental studies of nitromethane flames and evaluation of kinetic mechanisms. Combust Flame 2018;190:327-36. doi:10.1016/j.combustflame.2017.12.011.

[31] Shrestha KP, Seidel L, Zeuch T, Mauss F. Kinetic Modeling of NOx Formation and Consumption during Methanol and Ethanol Oxidation. Combust Sci Technol 2019;191:1628-60. doi:10.1080/00102202.2019.1606804.

[32] Shrestha KP, Seidel L, Zeuch T, Mauss F. Detailed Kinetic Mechanism for the Oxidation of Ammonia Including the Formation and Reduction of Nitrogen Oxides. Energ Fuels 2018;32:10202-10217. doi:10.1021/acs.energyfuels.8b01056.

[33] Hoyermann K, Mauss F, Olzmann M, Welz O, Zeuch T. Exploring the chemical kinetics of partially oxidized intermediates by combining experiments, theory, and kinetic modeling. Phys Chem Chem Phys 2017;19:18128-46. doi:10.1039/C7CP02759A.

[34] Gao Z, Yang M, Tang C, Yang F, Yang K, Deng F, et al. Measurements of the High Temperature Ignition Delay Times and Kinetic Modeling Study on Oxidation of Nitromethane. Combust Sci Technol 2019:1-22. doi:10.1080/00102202.2019.1565533.

[35] Jia Z, Wang Z, Cheng Z, Zhou W. Experimental and modeling study on pyrolysis of n-decane initiated by nitromethane. Combust Flame 2016;165:246-58. doi:10.1016/J.COMBUSTFLAME.2015.12.010.

[36] Weng J-J, Tian Z-Y, Zhang K-W, Ye L-L, Liu Y-X, Wu L-N, et al. Experimental and kinetic investigation of pyrolysis and oxidation of nitromethane. Combust Flame 2019;203:247-54. doi:10.1016/J.COMBUSTFLAME.2019.01.033.

[37] Nauclér JD, Nilsson EJK, Konnov AA. Laminar burning velocity of nitromethane + air flames: A comparison of flat and spherical flames. Combust Flame 2015;162:3803-9. doi:10.1016/J.COMBUSTFLAME.2015.07.017.

[38] Tian Z, Zhang L, Li Y, Yuan T, Qi F. An experimental and kinetic modeling study of a premixed nitromethane flame at low pressure. Proc Combust Inst 2009;32 I:311-8. doi:10.1016/j.proci.2008.06.098. [39] Zhang K, Li Y, Yuan T, Cai J, Glarborg P, Qi F. An experimental and kinetic modeling study of premixed nitromethane flames at low pressure. Proc Combust Inst 2011;33:407-14. doi:10.1016/j.proci.2010.06.002. 
[40] Vin N, Battin-Leclerc F, Le Gall H, Sebbar N, Bockhorn H, Trimis D, et al. A study of chlorobenzene pyrolysis. Proc Combust Inst 2019;37:399-407. doi:10.1016/J.PROCI.2018.05.067.

[41] Vin N, Battin-Leclerc F, Herbinet O. A study of thermal decomposition of bromoethane. J Anal Appl Pyrolysis 2018;136:199-207. doi:10.1016/J.JAAP.2018.10.005.

[42] Dean AM, Bozzelli JW. Combustion Chemistry of Nitrogen. Gas-Phase Combust. Chem., New York, NY: Springer New York; 2000, p. 125-341. doi:10.1007/978-1-4612-1310-9_2.

[43] Zhu RS, Lin MC. CH3NO2 decomposition/isomerization mechanism and product branching ratios: An ab initio chemical kinetic study. Chem Phys Lett 2009;478:11-6. doi:10.1016/J.CPLETT.2009.07.034.

[44] Homayoon Z, Bowman JM. Quasiclassical trajectory study of CH3NO2 decomposition via roaming mediated isomerization using a global potential energy surface. J Phys Chem A 2013;117:11665-72. doi:10.1021/jp312076z.

[45] Zhu RS, Raghunath P, Lin MC. Effect of roaming transition states upon product branching in the thermal decomposition of CH3NO2. J Phys Chem A 2013;117:7308-13. doi:10.1021/jp401148q.

[46] Vlasov PA, Kuznetsov NM, Petrov YP, Turetskii S V. Nitromethane Isomerization during Its Thermal Decay. Kinet Catal 2018;59:6-10. doi:10.1134/S0023158418010147.

[47] Zhang RQ, Han KL, Zhu RS, Lee CS, Lee ST. Ab initio/Rice-Ramsperger-Kassel-Marcus approach to carbon nitride formation: CH3NH2 decomposition. Chem Phys Lett 2000;321:101-5. doi:10.1016/S00092614(00)00322-5.

[48] Baulch DL, Cobos CJ, Cox RA, Esser C, Frank P, Just T, et al. Evaluated Kinetic Data for Combustion Modelling. J Phys Chem Ref Data 1992;21:411-734. doi:10.1063/1.555908.

[49] Baulch DL, Cobos CJ, Cox RA, Frank P, Hayman G, Just T, et al. Evaluated Kinetic Data for Combustion Modeling. Supplement I. J Phys Chem Ref Data 1994;23:847-8. doi:10.1063/1.555953.

[50] Goos E, Burcat A, Ruscic B. Third millenium ideal gas and condensed phase thermochemical database for combustion (with update from active thermochemical tables). vol. ANL-05/20. Argonne: 2005. doi:10.2172/925269.

[51] Burcat's Thermodynamic Database n.d. http://garfield.chem.elte.hu/Burcat/burcat.html (accessed December 5, 2018).

[52] http://logesoft.com/loge-software/ n.d.

[53] Shang Y, Shi J, Ning H, Zhang R, Wang H, Luo S. Ignition delay time measurements and kinetic modeling of CH4 initiated by CH3NO2. Fuel 2019;243:288-97. doi:10.1016/J.FUEL.2019.01.112.

[54] Moréac G, Dagaut P, Roesler JF, Cathonnet M. Nitric oxide interactions with hydrocarbon oxidation in a jet-stirred reactor at 10 atm. Combust Flame 2006;145:512-20. doi:10.1016/j.combustflame.2006.01.002.

[55] Seidel L, Moshammer K, Wang X, Zeuch T, Kohse-Höinghaus K, Mauss F. Comprehensive kinetic modeling and experimental study of a fuel-rich, premixed n-heptane flame. Combust Flame 2015;162:2045-58. doi:10.1016/j.combustflame.2015.01.002.

[56] Faghih M, Chen Z. Two-stage heat release in nitromethane/air flame and its impact on laminar flame speed measurement. Combust Flame 2017;183:157-65. doi:10.1016/J.COMBUSTFLAME.2017.05.013.

[57] Tricot JC, Perche A, Lucquin M. Gas phase oxidation of nitromethane. Combust Flame 1981;40:26991. doi:10.1016/0010-2180(81)90130-9.

[58] Atkinson R, Baulch DL, Cox RA, Hampson RF, Kerr JA, Troe J. Evaluated kinetic and photochemical data for atmospheric chemistry: Supplement IV: IUPAC subcommittee on gas kinetic data evaluation for atmospheric chemistry. Atmos Environ Part A Gen Top 1992;26:1187-230. doi:10.1016/09601686(92)90383-V. 
[59] Choi YM, Lin MC. Kinetics and mechanisms for reactions of HNO with $\mathrm{CH} 3$ and C6H5 studied by quantum-chemical and statistical-theory calculations. Int J Chem Kinet 2005;37:261-74. doi:10.1002/kin.20079.

[60] Miller JA, Melius CF, Glarborg P. The CH3+NO rate coefficient at high temperatures: Theoretical analysis and comparison with experiment. Int J Chem Kinet 1998;30:223-8. doi:10.1002/(SICI)10974601(1998)30:3<223::AID-KIN8>3.0.C0;2-U.

[61] Lund Thomsen E, Nielsen OJ, Egsgaard H. The reaction of nitromethane with hydrogen and deuterium atoms in the gas phase. A mechanistic study. Chem Phys Lett 1993;215:257-63. doi:10.1016/0009-2614(93)89297-U.

[62] Striebel F, Jusinski LE, Fahr A, Halpern JB, Klippenstein SJ, Taatjes CA. Kinetics of the reaction of vinyl radicals with NO: Ab initio theory, master equation predictions, and laser absorption measurements. Phys Chem Chem Phys 2004;6:2216-23. doi:10.1039/b401163e.

[63] Geppert WD, Eskola AJ, Timonen RS, Halonen L. Kinetics of the reactions of vinyl (C2H3) and propargyl (C3H3) radicals with NO2 in the temperature range 220-340 K. J Phys Chem A 2004;108:42328. doi:10.1021/jp0370167. 